\title{
Telemonitoring to Change Standard Diabetes Education and Management in a Rural Healthcare Practice
}

\author{
Kendra L. Barker
}

Follow this and additional works at: https://researchrepository.wvu.edu/etd

\section{Recommended Citation}

Barker, Kendra L., "Telemonitoring to Change Standard Diabetes Education and Management in a Rural Healthcare Practice" (2015). Graduate Theses, Dissertations, and Problem Reports. 5156.

https://researchrepository.wvu.edu/etd/5156

This Dissertation is protected by copyright and/or related rights. It has been brought to you by the The Research Repository @ WVU with permission from the rights-holder(s). You are free to use this Dissertation in any way that is permitted by the copyright and related rights legislation that applies to your use. For other uses you must obtain permission from the rights-holder(s) directly, unless additional rights are indicated by a Creative Commons license in the record and/ or on the work itself. This Dissertation has been accepted for inclusion in WVU Graduate Theses, Dissertations, and Problem Reports collection by an authorized administrator of The Research Repository @ WVU.

For more information, please contact researchrepository@mail.wvu.edu. 


\title{
Telemonitoring to Change Standard Diabetes Education and Management in a Rural Healthcare Practice
}

Kendra L. Barker, MSN, APRN, FNP-BC, CDE

\author{
Doctoral Capstone Project submitted \\ to the School of Nursing \\ at West Virginia University \\ in partial fulfillment of the requirements for the degree of \\ Doctor of Nursing Practice
}

\author{
Jennifer Mallow, Ph.D., Chair \\ Laurie Theeke, $\mathrm{Ph}$. D. \\ Renee Schwertfeger, M.S.N. \\ Department of Nursing
}

\author{
Morgantown, West Virginia \\ 2015
}

Keywords: Telemonitoring, diabetes, education, rural, healthcare, telemedicine Copyright 2015 Kendra L. Barker 


\title{
ABSTRACT \\ Telemonitoring to Change Standard Diabetes Education and Management in a Rural Healthcare Practice
}

\author{
Kendra L. Barker, MSN, APRN, FNP-BC, CDE
}

\begin{abstract}
Background: Type II Diabetes is associated with increased morbidity and mortality. Intense education and positive behavior reinforcement by healthcare professionals has been shown to enhance personal glycemic control for patients with Type II diabetes. However, limitations often prevent patient attendance at diabetes education classes. The purpose of this change project was to assess the efficacy of a telemonitoring intervention on glycemic control. Kotter's change process served as the conceptual underpinning for the project.
\end{abstract}

Objective: The overall objective was to implement a telemonitoring intervention based on Kotter's change process in a sample of adults with Type II diabetes who obtained care at a rural primary care clinic. The intervention provided education and advanced practice nurse-led management of diabetes. Evaluation outcome measures included glycemic control, enhanced patient knowledge, effectiveness, and feasibility of telemonitoring to improve glycemic control for adult patients with Type II diabetes, living in a rural area.

Methods: A literature search was performed guided by the PICOT question "In adult patients with diabetes, does education by telephone affect blood glucose control?" Seven Randomized Control Trials (RCTs) and one cohort study were reviewed, all of which were quantitative studies, as well as a systematic review on telemonitoring for chronic diseases. Based on the information from these articles, a telemonitoring intervention was developed. The intervention methods included development of a telemonitoring dialogue based on the seven essential components of diabetes education per the AADE7, and introduction of a SMART plan to launch a change project for a rural healthcare clinic to include telemonitoring for diabetes education and management. The change process was guided by Kotter's change theory.

Results: The telemonitoring intervention was performed on a group of ten participants. Eight participants completed the intervention, with an attrition rate of $20 \%$. Mean blood glucose values for the eight participants decreased from $213 \mathrm{mg} / \mathrm{dL}$ to $153 \mathrm{mg} / \mathrm{dL}$. However, the findings were not statistically significant (p-value 0.107 ). Based on post intervention feedback, patient and providers reported satisfaction with the telemonitoring intervention for education and management. Feasibility was hindered by lack of reimbursement for this type of intervention due to reimbursement criteria currently in place for telemonitoring, as well as time and staffing constraints.

Discussion: While findings for blood glucose levels were not statistically significant, likely due to the small sample size, patients experiencing these type of blood glucose reductions may see significant reductions in morbidity and mortality from diabetes. Patients and providers may also experience greater satisfaction implementing this type of intervention. Telemonitoring 
interventions for diabetes education and management have demonstrated effectiveness in the literature, and could be offered as an alternative to face-to-face interventions. However, due to lack of reimbursement and the large amount of time needed to implement, telemonitoring in this rural clinic may not be routinely implemented in the future. 


\section{Acknowledgments}

I would like to start by thanking my Lord and Savior, Jesus Christ, who has brought me through according to His plan for me and sustained me at all times as I have persisted through this program. Next, I thank my husband, John, and children, Daniel \& Isaac, for their love and support. I hope to inspire a great respect for higher education and learning into Daniel-he is my sunshine! For Isaac, he is my rainbow, my promise from God that He will always be there. I have many other family members who are integral in my being able to complete this degree, and I love and thank them all (like Mom and Sharon). My Daddy is the wind beneath my wings! My passion for caring for patients with diabetes stems from my love for my Grandma Snider and Aunt Dotty. I have always been reminiscent of Grandma's pride in my becoming a nurse just before she went on to heaven, and I have been inspired to care for others with diabetes in her memory.

Professionally, I must first thank my chairperson, Jennifer Mallow for her guidance, determination and oversight in the completion of this project. We both grew in perseverance! Next, I thank Laurie Theeke, for her leadership and research savvy in rounding out our committee. I also wish to thank committee member Renee Schwertfeger, a fellow NP colleague who provided diabetes expertise as well as friendship to me. After my committee, I want to thank the various professionals that have surrounded me in the WVU SON faculty, the Preston Urgent Care Family Practice, LLC. Staff, and my wonderful patients who made this project possible! The final thanks goes to my fellow DNP students, including my besties Doris \& Toni, for all of the companionship and support as we worked our way through. I'm the last of the five of us to graduate, so I can say, "We did it!" My love to all 


\section{Table of Contents}

Acknowledgments

Table of Contents $\quad \mathrm{V}$

Introduction 1

Background 1

Significance of the Problem 2

Problem Statement 3

Description of Priority Population and Needs Assessment 3

Change Model Framework $\quad 5$

$\begin{array}{lr}\text { Literature Review and Synthesis } & 6\end{array}$

Methodology and Search Strategy $\quad 6$

$\begin{array}{ll}\text { Literature Review Synthesis } & 7\end{array}$

$\begin{array}{ll}\text { Literature Review Discussion } & 9\end{array}$

$\begin{array}{ll}\text { Literature Review Conclusion } & 11\end{array}$

$\begin{array}{ll}\text { Project Description and Design } & 11\end{array}$

Congruence of the Organizational Strategic Plan to Project $\quad 11$

$\begin{array}{ll}\text { Measurable Project Objectives } & 13\end{array}$

$\begin{array}{ll}\text { Measurement Tools } & 13\end{array}$

Evidence Based Project/Intervention Plan 15

Timeline of Project Phases 16

$\begin{array}{ll}\text { Resources } & 16\end{array}$

$\begin{array}{ll}\text { Personnel } & 16\end{array}$

$\begin{array}{ll}\text { Materials } & 17\end{array}$ 
$\begin{array}{ll}\text { Budget and Financial Plan } & 17\end{array}$

Evidence of Key Site Support $\quad 17$

$\begin{array}{lr}\text { Evaluation Plan } & 18\end{array}$

$\begin{array}{ll}\text { Goal } 1 & 18\end{array}$

$\begin{array}{ll}\text { Goal } 2 & 21\end{array}$

$\begin{array}{ll}\text { Results } & 22\end{array}$

$\begin{array}{ll}\text { Sample } & 22\end{array}$

$\begin{array}{ll}\text { Evaluation of Goals } & 22\end{array}$

$\begin{array}{ll}\text { Goal } 1 & 22\end{array}$

$\begin{array}{ll}\text { Goal } 2 & 29\end{array}$

Discussion and Recommendations $\quad 31$

Change Model Framework Results 31

Recommendations for the Site $\quad 34$

Recommendations for the Application to Other Settings 35

Discussion of the Project Process and Outcomes 35

$\begin{array}{ll}\text { Attainment of DNP Essentials } & 37\end{array}$

$\begin{array}{ll}\text { Appendices } & 39\end{array}$ 


\section{Index of Appendices}

Appendix A

Table 1. Comparison of Intervention Methods and Outcomes

between Studies

Table 2. Individual Call Info for Number of Calls, Amount of

Time Spent on Calls, and Change in Glucose

Table 3. Telephone Time Data for Week, Topic, and Length of

Call Time

Appendix B

Evaluation of Change Project Using Kotter's Change Process

(Pre-test)

(Post-test)

Appendix C

Behavior Score Dashboard

(Pre-test)

(Post-test)

Appendix D

Diabetes Demographic Data Collection Tool

(Time 1, Pre-Intervention)

(Time 2, After Intervention)

Appendix E

Capstone Project Flowsheet

Appendix F

AADE7 Self-Care Behaviors and Goals Telephone Guide to

Weekly Calls

Appendix G

SMART Workplan

Appendix $\mathrm{H}$

Capstone Budget Plan Form and Justification

77

Appendix I

Preston Urgent Care Family Practice, LLC. Site Support Letter

78 
Appendix $\mathbf{J}$

Score Dashboard Questions
79

81 
This capstone project was designed to change diabetes education and management in a rural clinic. The project is based on Kotter's validated change process (Kotter, 2006). This change in diabetes education and management was planned to target adult patients with poorly controlled Type II diabetes, and implement telemonitoring to assist patients in achieving improved clinical outcomes of care.

\section{Background}

Diabetes is an endocrine disorder that occurs with high blood glucose levels and inadequate insulin levels that persist over time (Valdez, Yoon, Liu, \& Khoury, 2007). As individuals age, the body's production of insulin is either too low or the body's cells develop insulin resistance and require higher amounts of insulin to continue normal function (Deshpande, Harris-Hayes, \& Schootman, 2008). Diabetes is recognized by the American Diabetes Association as a glycosylated hemoglobin (A1C) level of $>6.5 \%$, which is comparable to an estimated average blood glucose level of $140 \mathrm{mg} / \mathrm{dL}$ (American Diabetes Association [ADA], 2012). Optimal glycemic control is achieving an A1C to be less than $7 \%$, which is an estimated average blood glucose level of $154 \mathrm{mg} / \mathrm{dL}$ (ADA, 2012). The American Association of Clinical Endocrinologists advise patients with diabetes to strive for an A1C less than $6.5 \%$ for most favorable outcomes and glycemic control (American Association of Clinical Endocrinologists [AACE], 2013)

Diabetes is typically monitored with multiple daily glucose home monitoring and periodic glycosylated hemoglobin A1C measurements. Patients diagnosed with diabetes manage diabetes through dietary adjustments, exercise, self-monitoring of blood glucose levels, and medications in order to achieve glycemic control (ADA, 2012). This project aims to meet the 
Healthy People 2020 goals of reducing the ratio of patients with diabetes who have an A1C value greater than 9 percent, which equates to an average blood glucose level of $212 \mathrm{mg} / \mathrm{dL}$, and to increase the percentage of patients with diabetes with an A1C value less than 7 percent (ADA, 2012; Healthy People 2020, 2012).

\section{Significance of the Proposed Project/Intervention}

Diabetes is a macro-system, worldwide clinical problem with 382 million people living with diabetes internationally (International Diabetes Federation Fact Sheet, 2013). The United States has 18.8 million residents with diabetes (National Diabetes Fact Sheet, 2012). In West Virginia, diabetes has been identified in $12 \%$ of the population. Preston County, WV, the county where this project took place, $10.9 \%$ of the county population has been diagnosed with diabetes (County Health Rankings and Roadmaps, 2012; WV Diabetes Prevention and Control Program Surveillance and Statistics Fact Sheet, 2012). These sizeable numbers of patients with diabetes comprise a significant portion of the patients seeking healthcare, and present a challenge for healthcare providers to impact glycemic control.

Uncontrolled diabetes leads to extensive microvascular and neurological problems, and healthcare costs rise steeply for the care associated with complications of diabetes (Boyle et al., 2010). Morbidity and mortality are much higher among people with poorly controlled diabetes because of complications (Boyle et al., 2010). Diabetes is the primary cause of kidney failure, non-traumatic lower-limb amputations, and new cases of blindness, and is also a significant underlying health issue contributing to heart disease and strokes (Boyle, et al., 2010; Deshpande et al., 2008; National Diabetes Fact Sheet, 2012). In the United States, diabetes is a principal cause of death, ranked number seven over all diseases and causing significant mortality (Boyle, 
et al., 2010; National Diabetes Fact Sheet, 2012). People with diabetes have two times the risk of dying as compared to other people their age without diabetes (National Diabetes Fact Sheet, 2012).

Patients with diabetes often benefit from education and instruction to improve their glycemic control and prevent complications (Wolever, et al., 2010). Healthcare providers have an evolving role in managing patients with diabetes using personalized treatment strategies or educational "coaching" interventions (Wolever, et al., 2010). Healthcare providers may intervene with education and guidance for patients with diabetes to learn how to manage their disease. However, issues with non-adherence and poor attendance at face-to-face diabetes education sessions are challenges for diabetes educational interventions (Wolever, et al., 2010). Patients may have limited access to care including, limited transportation or lack of income that impede attendance at education sessions. However, attendance may be improved if the education is performed by telephone (Pare, Moqadem, Pineau, \& St-Hilaire, 2010).

\section{Problem Statement}

In the clinic of interest, there are over 100 patients that have been diagnosed with diabetes. According to chart audits in July 2013, 44\% of these patients were found to have poorly controlled diabetes with A1C levels above 7\%. This represents a substantial health concern for this clinic population. With the significant percentage of patients with uncontrolled diabetes, this health problem requires responsiveness from health care providers in the clinic.

\section{Description of Priority Population and Needs Assessment}

Adult persons with diabetes in the rural, Appalachian community of Preston County, WV are the population of interest for this project. West Virginia is the only state in the United States 
of America that is entirely geographically contained within the Appalachian mountain region. Preston County is therefore located in Appalachia, which is a rugged eastern U.S. mountainous region with distinct geographical and cultural isolation (Smith \& Tessaro, 2008). Needs assessed in this Appalachian population include various health disparities, cultural and terrain factors, and modifiable health risk factors.

Adults with diabetes in West Virginia face many healthcare challenges and health disparities, including below average income level, lower educational status, and poor access to care (Mallow, Theeke, Barnes, \& Whetsel, 2013). These disparities create the greatest needs assessed for this population. Of people age 25 or over, only $83.4 \%$ of West Virginians have completed a high school education, compared to 86.4\% nationwide (US Census Bureau 2010 Fact Finder, 2012). The annual median individual income for WV is $\$ 26,143$ compared to $\$ 27$, 319 nationally (US Census Bureau 2010 Fact Finder, 2012). Transportation to healthcare facilities from rural areas is challenging for many reasons, including travel time and expense, rugged terrain, rural road access, and road clearing during seasonal extreme weather (Huttlinger \& Purnell, 2008).

Appalachian communities are often culturally characterized as closeknit and closemouthed to outsiders, with a strong communal desire to care for their own people and problems (Behringer \& Friedell, 2006). An intervention delivered by healthcare providers that the patients already have an established relationship with may be more accepted. For this project, patients chosen for the intervention will already be established clinic patients. Hence, the nurse practitioner (NP) and the patients will already have familiar patient/provider communication in place. 
Obesity and decreased physical activity are the greatest modifiable risk factors for diabetes (Deshpande et al., 2008). The rate of obesity for Preston County is $34 \%$, compared to a national average of 25\% (County Health Rankings and Roadmaps, 2012). Many of the elements for obesity control are challenging for West Virginians, including diet, exercise, and health education. Diet may be compromised by the cost of food in a low-income state. Foods offered by public works are typically high in carbohydrates and starch, which lead to elevated blood glucose levels for persons with diabetes (Donnelly, 2003). In Preston County, the rate of physical inactivity is at $33 \%$, compared to the national benchmark of $21 \%$ (County Health Rankings and Roadmaps, 2012). There is limited access to recreational facilities, with a rate of 3 recreational facilities per 100,000 people compared to the national standard of 16 (County Health Rankings and Roadmaps, 2012). Modifying these risk factors may be supported by telemonitoring support and education to promote obesity reduction, increased physical exertion, and healthier dietary and nutritional intake (Pare, et. al., 2010).

\section{Change Model Framework}

The theoretical model for this change project is an 8-stage transformation process created by Kotter (2006). The following paragraph will describe each stage of Kotter's model as a framework. In the first stage, Kotter recommends that a sense of urgency be established to gain focus and attention on the problem at hand. The second stage that Kotter describes is to form a powerful guiding coalition (Kotter, 2006). The task here is to gather people with a common desire and commitment to change within the organization. This involves identifying the stakeholders and change champions who can help propel the project forward. Kotter's third, fourth, and fifth stages are to create a vision, followed by communicating the vision, and finally to empower the individual to act on that vision (Kotter, 2006). The sixth stage of Kotter's change 
process is to plan for and create short-term wins (Kotter, 2006). Consolidation of improvements and producing more change is the seventh stage in the change process (Kotter, 2006). This is an important part of the feedback process. The final eighth stage of Kotter's transformation process is to institutionalize the new approaches for sustainability (Kotter, 2006).

\section{Literature Review and Synthesis}

A non-exhaustive literature search was guided using the PICOT question "In adult patients with diabetes, how does education by telephone affect blood glucose control?" Information from the literature on diabetes education and management programs was extrapolated for details on implementation in the clinical setting. A critical appraisal was performed on the included literature for similarities and differences in design and findings, as well as strengths and weaknesses in intervention design and study design. Findings were synthesized and contributed to the proposed design of this evaluation project.

\section{Methodology and Search Strategy}

Following Larrabee's framework (2009), a non-exhaustive literature search was conducted, with the Cochrane Library, CINAHL, PubMed, Full Text databases (Academic Search Complete and Health/Nursing Academic Edition) and the National Guidelines Clearinghouse electronic databases, using keyword combinations of diabetes, telephone intervention, and A1C. Initially, the search yielded 1,489 articles for diabetes and telephone intervention. For diabetes, telephone intervention and A1C, the search yielded 158 articles. Limitations were then placed for relevancy to the PICOT question. Limits were placed on dates for the past 10 years (2002-2012), human subjects only, and language of English. Furthermore, the searches were limited to peer-reviewed journals, with an abstract, and with links to full text for convenience. Finally, upon review of the remaining articles, only articles pertaining to adult 
diabetes were considered. The use of snowballing and searching related articles resulted in four additional studies. A synopsis by Bloomgarden (2007) led to a study by Chen, et al. (2008). The final number of relevant evidence documents was 8, with 7 RCT studies and 1 cohort study.

Additionally, a systematic review article was identified by the search term “telemonitoring" that was not specific to diabetes but included various comorbid conditions. Diabetes was investigated in this article as a chronic disease. This systematic review by Pare, et al. (2010) found that in 63 studies there was an overall improvement in glycemic control.

\section{Literature Review Synthesis}

There is evidence to support telephone interventions to lower A1C levels in patients with diabetes. Five of the studies showed statistically significant lowering of A1C levels by telephone interventions (Chen, et al., 2008; Cinar, et al., 2010; Kim \& Oh, 2003; Sacco, et al., 2009; Walker, et al., 2011), while three studies did not (Frosch, et al., 2011; Maljanian, et al., 2005; Wolever, et al., 2010). Two of the studies found improvement in glycemic control for both the intervention and the control group, without a significant difference between groups. There was homogeniety in all of the studies with a clinical reduction in A1C levels, but some of the studies did not find results of statistical significance for glycemic control improvement. After viewing the comparisons of the study interventions, including the number of calls made for each intervention, and the outcomes for each study, it is noted that the number of calls may play an important part in efficacy for the outcome (see Appendix A, Table 1), and thereby in the heterogeniety of the findings. The three RCTs with insignificant results had low numbers of telephone call intensity during the intervention, which may have limited improvement in glycemic control. 
Gaps in knowledge exist related to how to best educate adult patients with diabetes and improve glycemic control. According to Walker et al. (2011), even though there are many effective interventions for diabetes, patients often do not reach their glycemic treatment goals. Of the various treatment options, behavioral interventions have been favorably therapeutic. Telephone interventions have been proposed as a personal, one-on-one intervention that can be tailored to help manage behaviors and outcomes for patients with diabetes (Walker, et al., 2011). Telephone care has been suggested as a cost-effective method of communicating with patients as a feasible and convenient way of providing support and education (Cinar, et al., 2010). Feasibility and convenience are enhanced by bringing diabetes management services into the patient's home (Kim \& Oh, 2003).

Gaps remain in the best design of telephone intervention (provision of accompanying literature or education, number of calls, length of intervention). There is also a gap in the applicability of the findings to general populations as the samples were primarily women in their fifties, limiting knowledge of how patients with diabetes of other age groups or gender might respond to a similar intervention. Additionally, all of the studies reviewed were conducted in urban areas. Notably, transportation in rural areas is more limited, and telephone interventions may make it easier for patients living in rural areas to receive care (Pare, et al., 2010; Smith \& Tessaro, 2008).

An additional unexplained finding was noted in three of the studies. Patients with a higher baseline $\mathrm{A} 1 \mathrm{C}$ were more likely to respond to the telephone interventions and show improvement in glycemic control outcomes (Chen, et al., 2008; Maljanian, et al., 2005; Wolever, et al., 2010). Hence, a gap remains in determining which patients with diabetes would be best- 
served with a telephone intervention based on glycemic control. The article by Chen, et al., (2008) discussed that while these patients with diabetes may be monitoring their blood glucose, they may not be doing anything about them even if they are elevated. Implementing an interactive telephone intervention to educate on management of elevated blood glucose levels may assist these patients in improving glycemic control (Chen, et al., 2008). One additional study used a telephone intervention to educate patients with diabetes about the importance of A1C monitoring to achieve optimal diabetes control (Coberley et al., 2007). This study described disease burden as relevant to glycemic control (Coberley, et al., 2007). All four of these studies were congruent in the findings that patients with poorer glycemic control and higher disease burden showed better improvement in glycemic control with telephone interventions (Chen, et al., 2008; Coberley, et al., 2007; Maljanian, et al., 2005; Wolever, et al., 2010.).

\section{Literature Review Discussion}

The results from this literature review have important implications for practice. Telephone intervention may be a more economical, convenient way to educate patients with diabetes and assist them with care management. Practice implications for this type of change would involve initial cost burdens for implementation, but would save money over time if costly diabetes complications were reduced. Healthcare costs are much higher for the care associated with complications of diabetes according to Boyle et al. (2010), so improving glycemic control with telephone interventions may provide healthcare cost savings by decreasing complications for patients with diabetes.

Telephone interventions may be more feasible than additional visits to healthcare centers because of the benefits to the patient related to transportation costs and accessibility. While all of 
the studies were conducted in urban areas, the applicability exists in rural populations as well because telephone education eliminates travel and access issues. Telephone interventions could be very beneficial methods for education in rural areas where patients with diabetes need to travel long distances to visit a healthcare provider.

One limitation of the studies include small sample size. Often the studies were performed on convenience samples in the area where an intervention was being delivered, and not to the population of patients with diabetes as a whole. This is likely because individual healthcare providers in these areas may have a sense of urgency to impact glycemic control in their individual populations, similar to the target population for the planned capstone project. While there is a technological movement toward telemonitoring as an acceptable intervention for healthcare providers, there may be payer reimbursement criteria that need to be met before certified diabetic educators can begin to use this type of intervention more freely. Another limitation was the high proportion of study patients that were women in their fifties, but this may be representative of the usual population of patients with diabetes who will voluntarily complete this type of intervention. The attrition rates of 33-34\% for previous studies completed were noted to be fairly common for similar populations. This rate of attrition provided some anticipatory guidance for the pilot project of a predictable attrition rate for this type of intervention.

An approximate number of recommended phone calls was not determined by any particular study, but those studies with the highest number of phone calls generally were weekly calls during at least the initial part of the intervention phase. This level of intensity appeared to have the greatest impact on glycemic control (Appendix A, Table 1). Thus, higher intensity of telemonitoring with more frequent phone education and management strategies early in the intervention may be more successful in improving glucose levels for patients. 
Using telephone interventions to enhance glycemic control is a means to help healthcare providers target uncontrolled diabetes. The Healthy People 2020 guidelines recommend increasing the percentage of patients with diabetes with an $\mathrm{A} 1 \mathrm{C}$ value less than 7 percent (Healthy People, 2012). With the evidence from this literature review showing that telephone interventions are successful for improving glycemic control, healthcare providers may consider telephone interventions to provide the diabetes management and education needed to meet these guidelines.

If telephone interventions were utilized for patients with diabetes, there might be significantly lower blood glucose levels, resulting in fewer complications from diabetes. Lowering of the blood glucose by even $17-18 \mathrm{mg} / \mathrm{dL}$ or $0.5 \% \mathrm{~A} 1 \mathrm{C}$ can help reduce complications for patients with diabetes (ADA, 2012). Morbidity and mortality for patients with diabetes could be decreased as glycemic control improves.

\section{Literature Review Conclusion}

Telephone interventions to provide diabetes education have been shown through research to assist with glycemic control. There is sufficient evidence to support a practice change for current diabetes disease management programs by adding telephone education to achieve better glycemic control. The best design for a telephone intervention for efficacy would involve frequent weekly phone calls. Patients with the best improvement in glycemic control may be those with the highest disease burden.

\section{Project Description and Design}

\section{Congruence of the Organization's Strategic Plan to Project}


The mission statement of Preston Urgent Care Family Practice, LLC, the clinic for this project, incorporates the values, goals and strategic plan of the organization. The mission statement is:

"to deliver patient-centered quality healthcare. Preston Urgent Care Family Practice, LLC. responds to the community healthcare needs by providing and coordinating excellent medical care for our patient and their families in a supportive environment. The values of Preston Urgent Care Family Practice, LLC. are committed to quality of care and setting high standards for excellence in the pursuit of improving the health and wellbeing of the patients we serve. As for the providers, Preston Urgent Care Family Practice, LLC. provides an atmosphere that promotes quality and provides an attractive and stimulating work environment. We strive to provide each provider with ample time for continuing education opportunities. We are dedicated to our employees and strive to provide an attractive and stimulating work environment. We are dedicated to serve the community. We strive to maintain professionalism and creativity." (Mission Statement, 2012).

The underlying goal for this project was to improve the health of patients with diabetes in the community. The mission statement for the clinic supported this pursuit. Providing excellent medical care and support for this rural population was enhanced through telephone support for the patients who are geographically challenged to travel long distances to obtain advanced diabetes education and support. The clinic also embraces creativity and a stimulating work environment for the providers, which provided underlying support for the ongoing research and practice advancement through projects like this. 


\section{Measurable Project Objectives}

The first goal of this project was to improve the ability of a rural healthcare practice in North Central West Virginia to educate and manage patients with diabetes. There were two aims to this goal: 1) To develop a detailed change management plan using Kotter's 8-Step Process for Leading Change to include telemonitoring, and 2) To evaluate the telemonitoring intervention for feasibility and acceptability. Accomplishing this aim included monitoring time spent on the development and implementation of the intervention, evaluating provider satisfaction, and tracking challenges encountered during the process. Pre and post- test surveys for evaluation of the telemonitoring intervention based on Kotter's change model as well as assessment of provider satisfaction were developed for this project (see Appendix B).

The second goal was to improve biophysical outcomes of patients with diabetes through the development of a diabetes education and management model to be delivered through telemonitoring. The approach involved a change in the former practice of diabetes education that consisted of a short patient dialogue and multiple handouts about diabetes. The new approach was an intensive educational process focusing on the seven key components of diabetes education and management that have been identified as the AADE7, which covers seven selfcare behaviors for patients with diabetes delivered by telephone. This delivery model was evaluated by measuring patient behaviors by questionnaire and biophysical outcome measurements. The approach involved the identification of patients to test this strategy and measuring patient reported blood glucose and body weight. All blood glucose values used for data analysis were self-reported, while weight data was obtained through chart review.

\section{Measurement Tools}


The time spent on development of this intervention was measured indirectly with the use of the SMART Workplan that was designed to map out a course for the project, and was then evaluated for how the course of the project followed the timeline.

Provider satisfaction was measured with a tool developed to evaluate how Kotter's Change Process guided the intervention and how using the process assisted in a successful outcome for the project (Appendix B). This questionnaire evaluates provider satisfaction at each stage of the change process using a ten point Likert scale. The tool was developed by the NP interventionist, so reliability and validity have not been confirmed.

Tracking challenges was done through documentation of the education and management telemonitoring program with a newly developed documentation flow sheet. This telemonitoring documentation flow sheet was developed to track interventions and challenges encountered in the study (Appendix E). The documentation flow sheet was completed over the course of the intervention to evaluate the number of phone calls, the primary feedback from the phone calls, and the average length of each phone call. The format that was developed to guide each call was developed using the AADE7 Self-Care Behaviors with focus bullets and talking points (Appendix F).

Glycemic control was measured by change in blood glucose levels prior to the telehealth intervention and after the telehealth intervention as measured by patient self-reported logs of weekly blood glucose measurements. Self-report is the method of choice because glucometer downloads would require either costly transmission devices or more frequent office visits which would be counterproductive to the purpose of telemonitoring. Pare, et al. (2010) found that selfreported glucose is a valid method for monitoring glycemic control. 
Additionally, patient behaviors were evaluated by the AADE7 Behavior Score Dashboard (BSD) tool (American Association of Diabetes Educators [AADE], 2013; Appendix C). This tool was designed to examine patient behaviors related to diabetes management, diabetes education and training, and to track patient progress. The BSD was developed as an evidence-based, data collection tool that can be used to initiate diabetes self-management education and training then track care planning and patient progress (AADE, 2013).

\section{Evidence Based Project/Intervention Plan}

Telemonitoring has developed with evolving technology in recent years (Polisena, Tran, Cimon, Hutton, McGill, \& Palmer, 2009). Basic telemonitoring involves a patient being monitored by a phone call periodically from the healthcare provider's office. More complex telemonitoring may include using digital or wireless technology devices to provide home monitoring and transmit biometrical information to the healthcare provider (Tompkins \& Orwat, 2010).

The practice change that was performed was a program with the delivery of telephone education and disease management for patients with poorly controlled diabetes. The protocol targeted patients with diabetes in the practice with an $\mathrm{A} 1 \mathrm{C}$ above $7.5 \mathrm{mg} / \mathrm{dL}$. A convenience sample was recruited from the clinic. Potential participants were able to volunteer for the study which was advertised by posters placed within the clinic. Demographic data was collected on a demographic data sheet developed to compile all of the pertinent data (see Appendix D) and also on the Behavior Score Dashboard tool (Appendix C). The process change included that the nurse practitioner perform a telephone intervention based on evidence-based diabetes guidelines. Incorporating some translation strategies, the NP used education sessions and education material 
for teaching diabetes management skills. The education material was obtained from the American Diabetes Association (ADA) as well as the American Association of Diabetes Educators (AADE), and was presented to the patients as well as to the clinic staff.

\section{Timeline of Project Phases}

The project was started with patient enrollment in the spring of 2014 with an expected duration of intervention delivery occurring over approximately three months. Telephone interventions were attempted weekly, because the most significant changes in glycemic control occurred with more frequent interventions in the review of the literature for evidence-based practice (Chen, et al., 2008; Kim \& Oh, 2003).

\section{Resources}

Personnel. The stakeholders include: the healthcare providers at the clinic, the clinic staff, and the patients with diabetes who are enrolled into the program. Additionally, a key stakeholder is the owner and administrator of the clinic, who is also a Nurse Practitioner (NP) at the clinic. One of the NPs was the primary interventionist, and staff assisted with the project through the provision of usual care and triage functions for the patients as needed. The NP interventionist also provided primary care for the patients in the project, along with the other clinic providers. The NP interventionist was responsible for the treatment fidelity for implementation of the project, ongoing program monitoring, and processing the feedback. The primary change champion for this intervention was the NP interventionist who was responsible for each task and phase in the implementation plan. A protocol was designed with a SMART Workplan (Appendix G) with periodic checkpoints and careful documentation to uphold a high standard of care (SMART Plan Development, 2013). 
Materials. The materials needed for implementation included educational information for the patients, and practice guideline information for the healthcare providers. Practice guidelines and focus points are in alignment with evidence-based practice according to the ADA and AADE. Patients were already supplied glucose monitors and glucometer test strips either through their insurance or as samples from the clinic. The staff and patient education materials were an assimilation of educational material from the ADA and AADE for education and management.

A template was developed for the electronic medical record in a flow sheet format, with check off areas for various points of diabetes education and management, and includes a free text area to make additional chart notes (Appendix E). This template was incorporated into the current electronic medical record as a scanned attachment. Patients were assigned individual identification numbers for privacy and security.

Budget and Financial Plan. The budget for this project was minimal since it was a small project being performed by a Doctoral Student who was also the NP interventionist. The NP interventionist who performed the intervention agreed to complete the hours of service regardless of salary reimbursement as part of an education project. Implementation and organizational costs for the clinic were minimal, as the NP interventionist already works for the clinic and provided reimbursable diabetes care for all clinic visits. Reimbursement for the telemonitoring visits was sought from third-party and private payers. Office supplies already in place were used for project implementation. The organizational contributions from the clinic reflect a portion of the current salary already in place for that provision of care (Budget Plan Form and Justification Worksheet, Appendix H).

\section{Evidence of Key Site Support}


The primary stakeholder is the NP who owns and manages the clinic, and she professed her commitment and support for the project (Appendix I). The staff at the clinic were willing to assist as needed for delivery of the intervention, and were supportive of improving processes and education/management for patients with diabetes. The mission statement for the clinic clearly expresses support for this type of intervention.

\section{Evaluation Plan}

Goal 1: To improve the ability of a rural healthcare practice in North Central West Virginia to educate and manage patients with diabetes.

Aim 1: To develop a telemonitoring intervention that could be implemented as a pilot project in a primary care clinic through a detailed change management plan using Kotter's 8-Step Process for Leading Change.

Goal 1, Aim 1 Evaluation Plan:

1) To develop a plan and timeline for implementation of the telemonitoring intervention. A SMART Workplan was created to outline expected development and implementation (Appendix G). The plan was designed to measure activities that went into developing and implementing this change process. The process was planned to take place over several months, leaving time at each stage of the workplan for each step to be completed. Kotter's 8Step Process for Leading Change guided the various steps of the SMART Workplan. Average amounts of time to complete each stage were estimated based on the NP interventionist's time allocated for the project (approximately 4 hours per week), and the amount of time spent on each step was noted in weeks to complete for evaluation purposes. 
Evaluation for the workplan was planned as met or not met with qualitative rationale added by the interventionist for detail. The following steps were planned.

a) Gain IRB approval and recommendations to ethically implement the project.

b) Meet with the clinic staff to introduce the project and review all the details so the staff would be able to provide feedback and become prepared for the project.

c) Finalize all documents for use during the project.

d) Formalize a contract with the clinic outlining the planned project.

e) Project enrollment, which included identifying potential patients as well as embracing voluntary patient participation in the project. This was done by answering questions and obtaining signed consent forms as well as assessing preliminary data with chart review and Behavior Score Dashboard pre-test results (Appendix C).

f) Initiate the telephone intervention and obtain blood glucose data.

g) Following regular telemonitoring visits, a review of the implementation of the project was planned to troubleshoot and obtain feedback on the change process.

h) After a three month period including any ongoing telemonitoring, evaluate the intervention at a follow-up diabetes visit by review of the blood glucose $\log$ and $\mathrm{A} 1 \mathrm{C}$ measurement.

i) After obtaining patient data, plan to collect provider post-surveys to obtain provider feedback on feasibility and effectiveness.

j) Collect the post-test Behavior Score Dashboard after completion of the project.

k) Complete review and analysis of the project, including the change process evaluation to determine the success of the capstone change project. 
Goal 1, Aim 2: To evaluate the telemonitoring intervention for feasibility and acceptability.

\section{Goal 1, Aim 2 Evaluation Plan:}

1) To monitor the time spent on the implementation of the intervention by recording the amount of time spent to implement the intervention with each patient. Time was planned to be measured in minutes on the Telemonitoring Tracking Flowsheet for the amount of time spent on each patient making phone calls. This was planned to evaluate the average length of time per call for each patient, for each week of education, and included the range from minimum to maximum amount of time spent. After this was measured for each patient, the data was compared and analyzed for the project as a whole.

2) To evaluate provider satisfaction of the telemonitoring intervention with pre and posttest surveys, and to assess the use of Kotter's 8-Step Process for Leading Change. Kotter's process was outlined in a provider questionnaire using a Likert rating scale for how important each step of the process was perceived to be by the provider, and qualitative feedback was elicited for perspectives on the change process. The questionnaire was developed to monitor the perception of the change process and provider satisfaction qualitatively with a Likert scale and an area for comments. The Likert scale included rating the importance of each step in the change process between 1 (low) and 10 (high), with differences pre and post-test planned to be evaluated by paired t-test statistical analysis. The provider satisfaction instrument (Appendix B) was planned to be given to the 4 providers that were delivering care at the time of the enrollment process. 
3) To track challenges encountered during the process. This data was planned to be collected through implementation and evaluation of the SMART Workplan as being met or not met with qualitative rationales, feedback on the change process as noted on the provider pre and post surveys, and on the Telemonitoring Tracking Flowsheet completed throughout the telemonitoring intervention.

Goal 2: To improve biophysical outcomes of patients with diabetes through the implementation of a diabetes education and management model to be delivered through telemonitoring.

Goal 2, Aim 1: To improve biophysical outcomes of diabetes through implementation of an intensive educational process delivered by telephone.

Goal 2, Aim 1 Evaluation Plan:

1) To evaluate weight differences pre implementation and post implementation obtained through chart review. Weight data was planned to be collected for pre and postintervention and was to be analyzed using a paired t-test analysis.

2) To evaluate fingerstick blood glucose differences pre-implementation and postimplementation obtained through patient self-report. Blood glucose data was planned to be collected through self-report for pre and post-intervention data. The plan was to analyze this data with a paired t-test analysis.

3) To evaluate changes in behaviors that occurred as a result of the intervention, the patient Behavior Score Dashboard instrument was given as a pre and post-test (Appendix C). Comparing answers with a paired t-test analysis was planned to evaluate for differences in behavior related to the intervention. 


\section{Results}

\section{Sample}

A convenience sample of 10 patients was established for this pilot study. Inclusion criteria for the project included: being a current primary care patient of the rural clinic, 18 years old or older, English-speaking, being willing to participate in the project with telephone access, an $\mathrm{A} 1 \mathrm{C}$ of $7.5 \%$ or higher, and having a diagnosis of Type 2 diabetes. Exclusion criteria for the project included children under the age of 18, non-English speaking, without telephone access, or an $\mathrm{A} 1 \mathrm{C}$ under $7.5 \%$.

There were a total of 10 participants. Age ranged from 35-56 years, with a mean of 47.5 years. There were 3 males and 7 females, and 100\% of the sample was white, Caucasian. Eighty percent of the sample was married. The average duration of having diabetes was 7.5 years, with a range of 0.3 to 21 years. Twenty percent of the patients had previously had diabetes education. The average pre-intervention $\mathrm{A} 1 \mathrm{C}$ was $9.39 \%$, with a range of $7.8 \%$ to $12.0 \%$. Patients were on various types of therapy, including oral agents, insulins, injections, and different combinations of these as well.

\section{Evaluation of Goals}

Goal 1: To improve the ability of a rural healthcare practice in North Central West Virginia to educate and manage patients with diabetes.

Aim 1: To develop a detailed change management plan using Kotter's 8-Step Process for Leading Change to include telemonitoring 
Goal 1, Aim 1 Results:

2) A SMART Workplan was created as a plan and timeline for the telemonitoring intervention to outline expected development and implementation (Appendix G). Evaluation for the workplan was planned as met or not met with qualitative rationales for detail. The following steps were evaluated.

a) Gain IRB approval and recommendations to ethically implement the project.

i) None of the steps were met according to the timeframe first plotted in the SMART Workplan because of the amount of time actually used to complete this first step. It took three months to meet IRB approval. An average amount of time spent each week on this process was 4 hours, with a total time spent on this step was 48 hours.

b) Meet with the clinic staff to introduce the project and review all the details so the staff would be able to provide feedback and become prepared for the project prior to launching the intervention.

i) This step was met over the fourth month, for a total time spent of 16 hours.

Educational handouts were reviewed and assessed by staff for use during the project. Clinic staff was coached to refer all project specific patient questions to the NP interventionist.

c) Finalize all documents for use during the project.

i) This step was while completing the IRB process because all documents were required to meet IRB approval prior to use.

d) Formalize a contract with the clinic outlining the planned project. 
i) This task was also met within the timeframe of IRB approval since it was required for IRB.

e) Project enrollment, which included identifying potential patients as well as embracing voluntary patient participation in the project. This was done by answering questions and obtaining signed consent forms as well as assessing preliminary data with chart review and Behavior Score Dashboard pre-test results (Appendix C).

i) Early in the project enrollment phase, various clinic staff spent time explaining the posters, the project, and the enrollment process to interested patients. This time was brief for each episode as it was part of a usual clinic visit. Nurse Practitioner time was spent contacting the patients, initiating the telemonitoring intervention, and managing the care for the patients. Time was also spent reviewing charts, obtaining preliminary data and getting all consent forms completed correctly since initially the clinic staff failed to get all forms signed appropriately. Altogether, this step took 2 months to meet, with 32 hours of NP interventionist time spent on this phase.

f) Initiate the telephone intervention and obtain blood glucose data.

i) Variable amounts of time were spent on this step according to the amount of education delivered to each patient, averaging 2-4 hours per week for the first two months, then there was some downtime followed by an increase in time spent again in the last month of the study. Time spent on each phone call was tracked on the Telemonitoring Tracking Flowsheet, and total time spent was 746 minutes or 12.4 hours (see Table 2, Appendix A for individual call times).

g) Following regular telemonitoring visits, a review of the implementation of the project was planned to troubleshoot and obtain feedback on the change process. 
i) This step was met in part through review of the provider satisfaction survey for feedback received in a preceding step, but also in informal feedback that was received from other staff at the clinic and from the NP interventionist.

h) After a three month period including any ongoing telemonitoring, evaluate the intervention at a follow-up diabetes visit by review of the blood glucose log and A1C measurement.

i) This step was met with a follow-up clinic visit for eight of the participants, but not all were able to complete the planned visit. Two patients did not complete the intervention or return to clinic after the intervention started.

i) After obtaining patient data, plan to collect provider post-surveys to obtain provider feedback on feasibility and effectiveness.

i) There was only one post-survey possible due to turnover in the clinic staff from the time of initiation to the time of completion. Eight hours were spent on reviewing the information from this step and the previous one.

j) Collect the post-test Behavior Score Dashboard after completion of the project.

i) The post-test Behavior Score Dashboard (BSD) was collected as planned to meet the next step for the eight participants still active in the study. BSD pre and post data was entered into SPSS for data analysis (SPSS, 2014).

k) Complete review and analysis of the project, including the change process evaluation to determine the success of the capstone change project.

Total time spent on this step was 8 hours. This included the change process evaluation to measure the success of the capstone change project, and the BSD evaluation 
from the previous step. Altogether, 124 hours were spent on the development, implementation and evaluation of the project.

\section{Goal 1, Aim 2 Results:}

1) Time was measured in minutes on the Telemonitoring Tracking Flowsheet for the amount of time spent on each patient making phone calls. The total time spent on each patient was collected. A total of 12.4 hours was spent on this intervention part of the project. The planned evaluation was to detail the average length of time per call for each week of education as well as the range from minimum to maximum amount of time spent (see Table 3).

2) To evaluate provider satisfaction of the telemonitoring intervention with pre and posttest surveys. There was only one post-survey possible due to turnover in the clinic staff from the time of initiation to the time of completion. The survey tool was designed to be integrated with a Likert tool to monitor the change process in a measurable way as well as to collect provider satisfaction qualitative information. Qualitative responses were noted to be positive on the provider satisfaction/change evaluation survey, and were described by Kotter's 8 Stages (Kotter, 2006). Kotter's process was measured by a Likert rating scale for how important each step of the process was perceived to be by the provider, and qualitative feedback was elicited for perspectives on the change process. Quantitatively, there were no Likert numerical changes in pre and post perception in the importance of each step of the process, so numerically there were no statistically significant differences in the Likert rating scale pre and post intervention. Qualitatively, there were comments offered by the provider as follows. For Stage 1, to establish a sense of urgency, the pre-test response included, "need motivated staff for success" and post- 
test, "noted cooperation from staff," and "greatly improved patient services." For Stage 2, to form a powerful guiding coalition, the pre-test feedback included, "Need effective leaders," and the post-test response noted, "Excellent teamwork with this project." Stage 3 , create a vision, was described by the provider pre-test as, "all persons on same page," and post-test as, "vision is clear and directed to improve patient outcomes." Stage 4 was about communicating the vision, and pre-test feedback was, "group needs to be interested, motivated and thoroughly understand the vision," while the post-test response was that, "communication was excellent throughout the process." Stage 5 is to empower others to act on the vision, which the provider pre-test survey described by remarking, "If do not empower others in plan to achieve vision, end result could be disastrous," and evaluated post-test by noting that the "staff acted/planned vision well." For Stage 6, the plan for and creation of short-term wins was embraced in the pre-test survey by the provider stating that "short-term goals ... assist in attaining ultimate vision," and followed with noting how "focus increased on various aspects of care" in the post-test survey. Stage 7 is about consolidating improvements and producing more change, which the provider noted on the pre-test as, "change always involves...evolving improvement," and reflected on the post-test as, "care improved with foot checks, urine testing, management of meds, referrals; use of new meds." Stage 8 is institutionalizing the new approaches, which the provider noted in the pre-test as "needs ongoing monitoring," and further described in the post-test as "consistent behavior/care practice for ongoing success."

3) There were many challenges met as the intervention took place. Obstacles and challenges were analyzed by evaluation of the SMART Workplan process, feedback on the change process from the providers, and on the Telemonitoring Tracking Flowsheet. 
a. SMART Workplan evaluation for challenges.

i. The consent process was problematic. Many patients signed the forms incorrectly or missed signature lines and had to return to the clinic to complete the forms.

ii. Total time spent on the project was more than anticipated as several steps took longer to complete than expected, including the IRB process and the enrollment process.

iii. Reimbursement for telemonitoring was found to require certification as a qualified center and provided to particular identified rural areas, neither of which was applicable to this study.

b. Provider feedback challenges.

i. A high rate of staff turnover occurred in the clinic, making it challenging to obtain provider and staff data consistently.

ii. The clinic is an urgent care in addition to being a primary care clinic, so as business increased for the clinic, staff time to work on the project was inhibited. For the intervention to be feasibly performed with telemonitoring phone calls made in a regular fashion, extra staff time would need to be allotted for this in addition to regular duties.

c. Telemonitoring Tracking Flowsheet challenges.

i. After initiating the telephone contact, some patients preferred texting to leaving messages, so some contact was completed in this format.

ii. As the telemonitoring intervention rolled out, there were patients who did not return calls or participate in all of the planned sessions. 
Goal 2: To improve biophysical outcomes of patients with diabetes through the development of a diabetes education and management model to be delivered through telemonitoring.

Aim 1: To improve biophysical outcomes of diabetes through implementation of an intensive educational process delivered by telephone.

\section{Goal 2, Aim 1 Results:}

1) Means for weight in pounds both pre-intervention and post-intervention were compared using a paired samples t-test and SPSS for data analysis (SPSS, 2014). There was no statistically significant decrease in weight from Time 1 (M 213, SD 59.78) to time 2 (M $210, \mathrm{SD} 60.52), \mathrm{t}(7)=0.889, \mathrm{p}=0.404$ (two-tailed). The mean decrease in weight was 3 pounds with a $95 \%$ confidence interval range from -4.98 to10.98.

2) A paired samples t-test with SPSS analysis was used to compare means of preintervention blood glucose values in $\mathrm{mg} / \mathrm{dL}$ to post-intervention blood glucose values (SPSS, 2014). There was no statistically significant decrease in glucose levels from Time $1(\mathrm{M} 213.75, \mathrm{SD} 87.10)$ to time $2(\mathrm{M} 153.38, \mathrm{SD} 43.10), \mathrm{t}(7)=1.849, \mathrm{p}=0.107$ (twotailed). The mean decrease in blood glucose was $60.375 \mathrm{mg} / \mathrm{dL}$ with a $95 \%$ confidence interval range from -16.85 to 137.595 .

3) Behavior Score Dashboard data was compared for pre and post-intervention differences, see data in Appendix J. Questions on the seven issues (being active, healthy eating, reducing risks, taking medications, monitoring glucose, problem solving and healthy coping) identified by the AADE7 protocol were matched from pre-test BSD to post-test BSD and analyzed using SPSS for differences (SPSS, 2014). There were only three 
questions that showed statistically significant differences $(p \leq 0.05)$ in the answers from Time 1 to Time 2 . The first two questions were about being active, and the third about monitoring:

a. During the past week, how many days were you able to be active, answer 1-7 days?

i. There was a statistically significant increase in the number of days a patient was able to be active from Time 1 (M 4.29, SD 1.89) to time 2 (M 6.29, SD 1.496), $\mathrm{t}(6)=-2.449, \mathrm{p}=0.050$ (two-tailed). The mean increase in days was 2 with a 95\% confidence interval range from -3.998 to -0.002 .

b. How important is it to you to be active, where 0 is not important at all and 10 is very important?

i. There was a statistically significant increase in how important being active was to patients from Time $1(\mathrm{M} 7.88, \mathrm{SD} 1.55)$ to time 2 (M 9.25, SD 0.886), $\mathrm{t}(7)=-1.418, \mathrm{p}=0.020$ (two-tailed) on a Likert scale. The mean increase in importance was 1.375 with a $95 \%$ confidence interval range from -2.464 to -0.286 .

c. How sure are you that you can take your medicines, where 0 is not sure at all and 10 is very sure?

i. There was a statistically significant increase in how sure patients were about taking medications from Time 1 (M 10, SD 0) to time 2 (M 9.38, SD $0.518), \mathrm{t}(7)=3.416, \mathrm{p}=0.011$ (two-tailed) on a Likert scale. The mean 
increase in assurance was 0.625 with a $95 \%$ confidence interval range from 0.192 to 1.058 .

\section{Discussion and Recommendations}

Change Model Framework Results. The theoretical model used for this change project was Kotter's transformation process (2006). The following paragraphs will describe each stage of Kotter's model as a framework and how this framework was operationalized in this change project. Pre and post- test surveys were developed to assess the utilization and implementation of Kotter's change model for the capstone project.

In the first stage, Kotter recommends that a sense of urgency be established to gain focus and attention on the problem at hand. For this project, the startling rate of patients with uncontrolled diabetes was alarming for healthcare providers. In the clinic of choice for this intervention, the healthcare providers were surprised to realize that almost half of the population of patients with diabetes was uncontrolled. The high percentage of poorly controlled patients with diabetes created a sense of urgency to intervene since the risk for developing complications greatly increases the morbidity and mortality for patients with diabetes (Boyle, et al., 2010;

National Diabetes Fact Sheet, 2012). The provider surveyed from the pilot project site described the need for the staff to be motivated for success in this stage, and noted post-intervention that staff cooperation greatly improved patient results. Highlighting the prevalence of uncontrolled diabetes within the clinic site seemed to place impetus on the clinic staff.

The second stage that Kotter describes is to form a powerful guiding coalition (Kotter, 2006). For this project, the primary coalition for the clinic was the NP interventionist, the NP owner/manager of the clinic, and the nursing staff. The staff was informed of the prospective 
project, and meetings were held with the key stakeholders. The group pledged their support for the project, forming a supportive coalition for telemonitoring care for patients with diabetes. As noted by the provider pre and post survey, the "need for effective leaders was recognized" and teamwork was "excellent," so the guiding coalition appeared to be very effective for this site.

Kotter's third, fourth, and fifth stages are to create a vision, followed by communicating the vision, and finally to empower the individual to act on that vision (Kotter, 2006). The vision for this project was created specifically for this clinic and the population of patients with diabetes. The vision was to improve diabetes education and management in a rural primary care clinic using a telemonitoring process. This was accomplished by choosing patients with poorly controlled diabetes and assisting those patients in achieving better glycemic control. A detailed strategy using the SMART Workplan (Appendix C) was created. The developed SMART workplan was used at the clinic to communicate an outline for the project. By providing the detailed outline as well as regular staff meetings, the goal was to empower the staff to participate in the project and provide feedback for the ongoing project. According to the provider pre and post survey, the vision for this site was communicated clearly to the staff and the staff worked well together to act on the vision, so this appeared to be an effective strategy for this clinic site.

The sixth stage of Kotter's change process is to plan for and create short-term wins (Kotter, 2006). Short-term wins that were expected included: an increase in collaboration of the staff at the clinic, improved diabetes education, improved diabetes management, and improvement in patient's glycemic control. The SMART Workplan was a stepwise plan of gradually introducing the project into the clinic and embracing feedback from the clinic staff (Appendix C). As the staff came together to provide input for the project, an expected short-term win included better teamwork in the form of collaboration on improving diabetes education 
delivery. Additionally, the focus on short-term blood glucose improvements versus long-term A1C changes was expected to produce short-term wins for glycemic control. Weekly blood glucose log evaluations provide short-term feedback and improvements in glucose levels are an anticipated short-term win for this project. The provider survey noted short-term wins as assisting in attaining the ultimate vision with an increased focus on various aspects of care.

Kotter recommends consolidation of improvements and producing more change as the seventh stage in the change process (Kotter, 2006). This is an important part of the feedback process. The project plan was to consolidate improvements and attempt to produce more desired changes through evaluation of patient and provider surveys. As the project was implemented, there were ongoing updates and upgrades as needed to facilitate the project based on patient and staff feedback. These perpetual changes were intended to improve the process of delivery. The provider survey qualitatively described change as "evolving improvement," and described some specific aspects of how care at this clinic improved due to the project in areas of foot care for patients with diabetes, and in diabetes referrals.

The final eighth stage of Kotter's transformation process is to institutionalize the new approaches (Kotter, 2006). The sustainability of this project depended on the success of the intervention in improving glycemic control, and improving the diabetes education process. While glycemic control was not statistically significantly improved, it was improved, and the telemonitoring diabetes education process was developed. Successful and adequate reimbursement for the amount of time spent delivering the intervention from payers was expected to provide greater sustainability, but reimbursement was unattainable. Additional success considered was provider satisfaction, which was noted throughout the post-test survey and mentioned as consistent behavior continuing for ongoing success and improved patient care 
in the final institutionalization of new approaches. Any one of these successes were thought to lend to the likelihood that this new approach would become integrated into the usual care at the clinic.

Recommendations for the Site. Having completed the project and obtaining the insights received throughout the implementation, there are suggestions for revision that might prove helpful for future projects. Since the SMART Workplan and utilization of Kotter's Change Process were successful at this clinic site according to the evaluations, these strategies would be recommended to design, implement and guide a similar change project.

In the literature there were no specific guides found to direct phone call interventions, so one was created for this project. For continuation of the project to occur, some revisions are suggested based on the feedback of the NP interventionist. Revising this guide to improve it for future use might include reducing the number of education delivery phone calls to three and condensing the previously planned seven phone dialogues into those three calls. The patients in this pilot study initially seemed eager to learn, and the first few phone calls were very lengthy. As time went on, the educational portion of the phone calls became much more brief and more focus was on management of ongoing issues. Phone call content in the first few sessions was quite heavy with discussing monitoring and diet, but then lightened up noticeably toward the end. Making a change now that this data has been obtained and analyzed might make the intervention more feasible by condensing the content of these calls together into less calls for education, while still allowing regular phone call follow-up for a longer period, to enhance management. Some of the patients slacked off on phone calls after a few weeks, then resumed again after a period of time. A consideration for this effect would be to plan monthly follow-up 
phone calls for a few months to help patients with questions that arise as well as accountability. This format might allow for better feasibility for the interventionist to complete calls to patients. Recommendations for Application to Other Settings. Feasibility to complete the patient workload for the study was affected by the high volume of clinic patients already being cared for, so realistically to implement this program into a similar setting would likely require modifications to achieve success. Time and staff would need to be allotted for the telemonitoring intervention. Reimbursement in settings approved for telehealth would be recommended, but the intervention might not be feasible in clinics such as this that do not meet the criteria that is currently approved for reimbursement. Utilizing Kotter's change process and a SMART Workplan were effective tools for the project process of implementing an intervention such as this. An unintended outcome noted in this study stemmed from implementing an audit, which as done early in the process, that helped highlight the need for change in the care of patients with diabetes.

Discussion of the Project Process and Outcomes. Eight participants completed the intervention, with an attrition rate of $20 \%$ for the study. This was better than the expected attrition rate of $33-34 \%$ noted in the literature review. The telemonitoring intervention was performed on a pilot study group of ten participants, which is a very small sample size that impacts the level of significance of the findings. At this sample size, even very large changes in values may not be statistically significant for the sample. The results for the study showed a change in mean blood glucose values decreasing from $213 \mathrm{mg} / \mathrm{dL}$ to $153 \mathrm{mg} / \mathrm{dL}$ but findings were not statistically significant. However, as a clinician, these changes in glycemic control may have significant yield for patients. Patients experiencing these type of blood glucose reductions may see significant reductions in morbidity and mortality from diabetes. 
According to the BSD pre and post-tests, there were also positive significant changes in behavior for being active and taking medications. Making these types of behavior adjustments in the short-time period of this pilot study is encouraging for future behavior modifications. These types of changes can directly impact glycemic control, and are important first steps in lifestyle alterations related to diabetes management.

Feasibility for this type of project may be limited due to the lack of potential reimbursement as well as the amount of staff time required for implementation. The estimated time spent was approximately 124 hours of staff time for ten patients, and without significant glycemic control improvements. Now that the SMART Workplan has been developed, and the Telephone Guidelines have been developed, the project could be replicated with a smaller amount of staff time required for implementation; however, prospective users of this plan would want to consider the pros and cons related to feasibility prior to utilization.

Patients and providers may also experience greater satisfaction implementing this type of intervention. A rapport develops between the patient and the provider, and the relationship is enhanced. While there may be an aspect of the Hawthorne effect with patients trying to gain better control over the diabetes just because they are in a study and hope to please the researcher, this also enhances accountability. This is an effect that could be studied in a qualitative design for deeper exploration.

Telemonitoring interventions for diabetes education and management have demonstrated effectiveness in the literature, and could be offered as an alternative to face-to-face interventions. While the literature review showed greater success with a greater number of phone calls, this finding was not supported by this project. The finding in the literature that patients with higher A1C levels had better success in A1C reduction with this type of intervention shows promise 
according to the findings from this study. Further and more extensive evaluation in rural underserved populations may provide necessary data to fully understand the feasibility, acceptability, and effectiveness of implementing this type of intervention with this specific population.

\section{Attainment of DNP Essentials}

Essential I. Scientific Underpinnings for Practice. This project had strong and rich content for meeting this essential in various ways, including exploring the health issue of diabetes, utilizing evidence-based research to improve management, and piloting a change project according to a theoretical framework.

\section{Essential II. Organizational and Systems Leadership for Quality Improvement and}

Systems Thinking. This essential was met through several aspects of the project, including performing an organizational audit to evaluate data for a group of patients with diabetes and then leading a process change within the organization to improve care for patients within this group. Essential III. Clinical Scholarship and Analytical Methods for Evidence-Based Practice. Performing the literature review for an evidence-based method of providing education and management for patients with uncontrolled diabetes, then proceeding to develop and implement the method as an intervention meets this essential.

Essential IV. Information Systems/Technology and Patient Care Technology for the Improvement and Transformation of Health Care. This essential is exemplified in this pilot project to introduce the utilization of current technologies in healthcare to improve health and transform healthcare delivery. 
Essential V. Health Care Policy for Advocacy in Health Care. Piloting a change project to impact current clinic policy for diabetes education and management, with the intention to disseminate the results for policy changes in similar clinics meets this essential.

Essential VI. Interprofessional Collaboration for Improving Patient and Population Health Outcomes. Utilizing Kotter's change process and the SMART Workplan to encourage clinic staff collaboration met this essential.

\section{Essential VII. Clinical Prevention and Population Health for Improving the Nation's}

Health. Focusing on a health issue of such prominence as diabetes, with the risks for morbidity and mortality, and working to address the problem with a project like this achieves this essential. Essential VIII. Advanced Nursing Practice. This essential has been met through the provision of exemplary care for the patients with uncontrolled diabetes through usual primary care provider methods as well as telemonitoring methods to attempt improvement of glycemic control. 


\section{Appendix A}

Table 1

Comparison of Intervention Methods and Outcomes between Studies

\begin{tabular}{|c|c|c|c|}
\hline Reference & $\begin{array}{l}\text { Approximate total } \\
\text { number of calls over } \\
\text { the intervention }\end{array}$ & $\begin{array}{l}\text { Length of time of the } \\
\text { intervention }\end{array}$ & $\begin{array}{l}\text { Change in } \mathrm{A} 1 \mathrm{C} \text { for } \\
\text { intervention group }\end{array}$ \\
\hline$($ Chen, et al., 2008)** & 24 & 6 months & $-2.3 \%$ \\
\hline$($ Cinar, et al., 2010)** & 8 & 3 months & $-1.1 \%$ \\
\hline $\begin{array}{l}\text { (Frosch, Uy, Ochoa, \& } \\
\text { Mangione, 2011) }\end{array}$ & 5 & 6 months & $-0.5 \%$ \\
\hline$(\mathrm{Kim} \& \mathrm{Oh}, 2003)^{*}$ & 12 & 3 months & $-1.2 \%$ \\
\hline $\begin{array}{l}\text { (Maljanian, Grey, } \\
\text { Staff, \& Conroy, } \\
2005)^{\text {NS }}\end{array}$ & 12 & 3 months & -1.2 \\
\hline $\begin{array}{l}\text { (Sacco, Malone, } \\
\text { Morrison, Friedman, \& } \\
\text { Wells, 2009) }\end{array}$ & 18 & 6 months & -1 \\
\hline (Walker, et al., 2011)* & 10 & 12 months & $-0.23 \pm 0.11 \%$ \\
\hline $\begin{array}{l}(\text { Wolever, et al., } \\
2010)^{\mathrm{NS}}\end{array}$ & 14 & 6 months & $-0.4 \%$ \\
\hline
\end{tabular}

Data are from the respective studies cited. * Studies with statistically significant findings at a level of $\mathrm{p}<0.05 ; * *$ Studies at a level of $\mathrm{p}<0.001$; ${ }^{\text {NS }}$ are those not significant. 


\section{Appendix A}

Table 2

Individual Call Information for Number of Calls, Amount of Time Spent on Calls, and Change in Glucose

\begin{tabular}{|c|c|c|c|}
\hline $\begin{array}{c}\text { Patient } \\
\text { ID }\end{array}$ & $\begin{array}{c}\text { Number of } \\
\text { calls }\end{array}$ & $\begin{array}{c}\text { Arranged by amount of time spent on calls in } \\
\text { minutes (total) }\end{array}$ & $\begin{array}{c}\text { Change in average } \\
\text { fasting glucose } \\
\text { (mg/dL) }\end{array}$ \\
\hline 3 & 13 & 117 & -31 \\
\hline 7 & 10 & 117 & -150 \\
\hline 19 & 7 & 105 & -185 \\
\hline 15 & 8 & 86 & -113 \\
\hline 14 & 9 & 85 & -55 \\
\hline 12 & 5 & 71 & Did not complete study \\
\hline 4 & 8 & 48 & +51 \\
\hline 11 & 12 & 45 & +80 \\
\hline 5 & 11 & 34 & \\
\hline 9 & 15 & 15 & Did complete study \\
\hline
\end{tabular}




\section{Appendix A}

\section{Table 3}

Telephone Time data for Week, Topic, and Length of Call Time

\begin{tabular}{|l|l|l|l|}
\hline & \multicolumn{1}{|c|}{ Topic } & $\begin{array}{c}\text { Time Range } \\
\text { for call (Min.- } \\
\text { Max) in } \\
\text { minutes }\end{array}$ & $\begin{array}{c}\text { Average length } \\
\text { of call time in } \\
\text { minutes }\end{array}$ \\
\hline Week 1 & $\begin{array}{l}\text { Taking } \\
\text { medications }\end{array}$ & $10-43$ & 29 \\
\hline Week 2 & $\begin{array}{l}\text { Glucose } \\
\text { monitoring }\end{array}$ & $5-39$ & 17 \\
\hline Week 3 & Diet & $8-45$ & 23 \\
\hline Week 4 & Exercise & $5-15$ & 9 \\
\hline Week 6 & Problem Solving & $5-10$ & 7 \\
\hline Week 7 & Healthy Coping & $5-8$ & 7 \\
\hline
\end{tabular}




\section{Appendix B}

\section{Evaluation of Change Project using Kotter's Change Process (Pre-test)}

Please describe how each stage of Kotter's Change Process might be utilized during the Change Project for Diabetes Education and Management in the clinic. An article brief by Kotter is attached for reference. Each stage is identified and then summarized. Please rate how important each stage appears to be for change to be successful on a Likert scale with 1 being particularly unimportant and 10 being extremely important. Then comment on things that might be done to fulfill each stage for the change project that is planned in the clinic.

Stage 1: Establish a Sense of Urgency. This stage includes convincing staff that continuing the current process is more dangerous than making a change.

$\begin{array}{llllllllll}1 & 2 & 3 & 4 & 5 & 6 & 7 & 8 & 9 & 10\end{array}$

Comments:

Stage 2: Form a Powerful Guiding Coalition. This stage involves assembling team members to work together toward the same goal, and choosing members who are leaders that will promote the change effort.

$\begin{array}{llllllllll}1 & 2 & 3 & 4 & 5 & 6 & 7 & 8 & 9 & 10\end{array}$

Comments:

Stage 3: Create a Vision. This stage entails presenting a vision to direct the change effort.

$\begin{array}{llllllllll}1 & 2 & 3 & 4 & 5 & 6 & 7 & 8 & 9 & 10\end{array}$

Comments:

Stage 4: Communicate the Vision. This stage requires discussion of the vision through conversation, strategies, and behaviors of the guiding coalition for the project.

$\begin{array}{llllllllll}1 & 2 & 3 & 4 & 5 & 6 & 7 & 8 & 9 & 10\end{array}$


Comments:

Stage 5: Empower Others to Act on the Vision. This stage involves encouraging others to take risks and contribute ideas and actions to the project. Additionally, organizational structures may need to be altered if they undermine the vision.

$\begin{array}{llllllllll}1 & 2 & 3 & 4 & 5 & 6 & 7 & 8 & 9 & 10\end{array}$

Comments:

Stage 6: Plan for and Create Short-Term Wins. This stage includes defining performance improvements and recognizing those as they are accomplished by staff.

$\begin{array}{llllllllll}1 & 2 & 3 & 4 & 5 & 6 & 7 & 8 & 9 & 10\end{array}$

Comments:

Stage 7: Consolidate Improvements and Produce More Change. This stage involves making the performance improvements into more permanent structures to change the system. Implementing the vision and developing it further with offshoot projects and new ideas are part of this stage as well.

$\begin{array}{llllllllll}1 & 2 & 3 & 4 & 5 & 6 & 7 & 8 & 9 & 10\end{array}$

Comments:

Stage 8: Institutionalize the New Approaches. This stage requires recognition of the new behaviors and successes for sustainability.

$\begin{array}{llllllllll}1 & 2 & 3 & 4 & 5 & 6 & 7 & 8 & 9 & 10\end{array}$

Comments: 
Reference: Kotter, J. (2006). Leading Change: Why Transformation Efforts Fail. Harvard Business Review.

\section{Leading Change: Why Transformation Efforts Fail}

Key ideas from the Harvard Business Review article by John P. Kotter

The Idea in Brief

Most major change initiatives - whether intended to boost quality, improve culture, or reverse a corporate death spiral — generate only lukewarm results. Many fail miserably.

Why? Kotter maintains that too many managers don't realize transformation is a process, not an event. It advances through stages that build on each other. And it takes years. Pressured to accelerate the process, managers skip stages. But shortcuts never work.

Equally troubling, even highly capable managers make critical mistakes - such as declaring victory too soon. Result? Loss of momentum, reversal of hard-won gains, and devastation of the entire transformation effort.

By understanding the stages of change — and the pitfalls unique to each stage - you boost your chances of a successful transformation. The payoff? Your organization flexes with tectonic shifts in competitors, markets, and technologies-leaving rivals far behind.

To give your transformation effort the best chance of succeeding, take the right actions at each stage - and avoid common pitfalls.

This HBR In Brief presents key ideas from a full-length Harvard Business Review article.

\section{Leading Change: Why Transformation Efforts Fail}

by John P. Kotter

\section{Leaders who successfully transform businesses do eight things right (and they do them in} the right order).

Editor's Note: Guiding change may be the ultimate test of a leader — no business survives over the long term if it can't reinvent itself. But, human nature being what it is, fundamental change is often resisted mightily by the people it most affects: those in the trenches of the business. Thus, leading change is both absolutely essential and incredibly difficult.

Perhaps nobody understands the anatomy of organizational change better than retired Harvard Business School professor John P. Kotter. This article, originally published in the spring of 1995, previewed Kotter's 1996 book Leading Change. It outlines eight critical success factors-from establishing a sense of extraordinary urgency, to creating short-term wins, to changing the culture ("the way we do things around here"). It will feel familiar when you read it, in part because Kotter's vocabulary has entered the lexicon and in part because it contains the kind of home truths that we recognize, immediately, as if we'd always known them. A decade later, his work on leading change remains definitive.

Over the past decade, I have watched more than 100 companies try to remake themselves into significantly better competitors. They have included large organizations (Ford) and small ones (Landmark Communications), companies based in the United States (General Motors) and elsewhere (British Airways), corporations that were on their knees (Eastern Airlines), and 
companies that were earning good money (Bristol-Myers Squibb). These efforts have gone under many banners: total quality management, reengineering, rightsizing, restructuring, cultural change, and turnaround. But, in almost every case, the basic goal has been the same: to make fundamental changes in how business is conducted in order to help cope with a new, more challenging market environment.

A few of these corporate change efforts have been very successful. A few have been utter failures. Most fall somewhere in between, with a distinct tilt toward the lower end of the scale. The lessons that can be drawn are interesting and will probably be relevant to even more organizations in the increasingly competitive business environment of the coming decade. The most general lesson to be learned from the more successful cases is that the change process goes through a series of phases that, in total, usually require a considerable length of time. Skipping steps creates only the illusion of speed and never produces a satisfying result. A second very general lesson is that critical mistakes in any of the phases can have a devastating impact, slowing momentum and negating hard-won gains. Perhaps because we have relatively little experience in renewing organizations, even very capable people often make at least one big error.

\section{Error 1: Not Establishing a Great Enough Sense of Urgency}

Most successful change efforts begin when some individuals or some groups start to look hard at a company's competitive situation, market position, technological trends, and financial performance. They focus on the potential revenue drop when an important patent expires, the five-year trend in declining margins in a core business, or an emerging market that everyone seems to be ignoring. They then find ways to communicate this information broadly and dramatically, especially with respect to crises, potential crises, or great opportunities that are very timely. This first step is essential because just getting a transformation program started requires the aggressive cooperation of many individuals. Without motivation, people won't help, and the effort goes nowhere.

Compared with other steps in the change process, phase one can sound easy. It is not. Well over $50 \%$ of the companies I have watched fail in this first phase. What are the reasons for that failure? Sometimes executives underestimate how hard it can be to drive people out of their comfort zones. Sometimes they grossly overestimate how successful they have already been in increasing urgency. Sometimes they lack patience: "Enough with the preliminaries; let's get on with it." In many cases, executives become paralyzed by the downside possibilities. They worry that employees with seniority will become defensive, that morale will drop, that events will spin out of control, that short-term business results will be jeopardized, that the stock will sink, and that they will be blamed for creating a crisis.

A paralyzed senior management often comes from having too many managers and not enough leaders. Management's mandate is to minimize risk and to keep the current system operating. Change, by definition, requires creating a new system, which in turn always demands leadership. Phase one in a renewal process typically goes nowhere until enough real leaders are promoted or hired into senior-level jobs.

Transformations often begin, and begin well, when an organization has a new head who is a good leader and who sees the need for a major change. If the renewal target is the entire company, the CEO is key. If change is needed in a division, the division general manager is key. 
When these individuals are not new leaders, great leaders, or change champions, phase one can be a huge challenge.

Bad business results are both a blessing and a curse in the first phase. On the positive side, losing money does catch people's attention. But it also gives less maneuvering room. With good business results, the opposite is true: Convincing people of the need for change is much harder, but you have more resources to help make changes.

But whether the starting point is good performance or bad, in the more successful cases I have witnessed, an individual or a group always facilitates a frank discussion of potentially unpleasant facts about new competition, shrinking margins, decreasing market share, flat earnings, a lack of revenue growth, or other relevant indices of a declining competitive position. Because there seems to be an almost universal human tendency to shoot the bearer of bad news, especially if the head of the organization is not a change champion, executives in these companies often rely on outsiders to bring unwanted information. Wall Street analysts, customers, and consultants can all be helpful in this regard. The purpose of all this activity, in the words of one former CEO of a large European company, is "to make the status quo seem more dangerous than launching into the unknown."

In a few of the most successful cases, a group has manufactured a crisis. One CEO deliberately engineered the largest accounting loss in the company's history, creating huge pressures from Wall Street in the process. One division president commissioned first-ever customer satisfaction surveys, knowing full well that the results would be terrible. He then made these findings public. On the surface, such moves can look unduly risky. But there is also risk in playing it too safe: When the urgency rate is not pumped up enough, the transformation process cannot succeed, and the long-term future of the organization is put in jeopardy.

When is the urgency rate high enough? From what I have seen, the answer is when about $75 \%$ of a company's management is honestly convinced that business as usual is totally unacceptable. Anything less can produce very serious problems later on in the process.

\section{Error 2: Not Creating a Powerful Enough Guiding Coalition}

Major renewal programs often start with just one or two people. In cases of successful transformation efforts, the leadership coalition grows and grows over time. But whenever some minimum mass is not achieved early in the effort, nothing much worthwhile happens.

It is often said that major change is impossible unless the head of the organization is an active supporter. What I am talking about goes far beyond that. In successful transformations, the chairman or president or division general manager, plus another five or 15 or 50 people, come together and develop a shared commitment to excellent performance through renewal. In my experience, this group never includes all of the company's most senior executives because some people just won't buy in, at least not at first. But in the most successful cases, the coalition is always pretty powerful - in terms of titles, information and expertise, reputations, and relationships.

In both small and large organizations, a successful guiding team may consist of only three to five people during the first year of a renewal effort. But in big companies, the coalition needs to grow to the 20 to 50 range before much progress can be made in phase three and beyond. Senior managers always form the core of the group. But sometimes you find board members, a representative from a key customer, or even a powerful union leader.

Because the guiding coalition includes members who are not part of senior management, it tends to operate outside of the normal hierarchy by definition. This can be awkward, but it is clearly 
necessary. If the existing hierarchy were working well, there would be no need for a major transformation. But since the current system is not working, reform generally demands activity outside of formal boundaries, expectations, and protocol.

A high sense of urgency within the managerial ranks helps enormously in putting a guiding coalition together. But more is usually required. Someone needs to get these people together, help them develop a shared assessment of their company's problems and opportunities, and create a minimum level of trust and communication. Off-site retreats, for two or three days, are one popular vehicle for accomplishing this task. I have seen many groups of five to 35 executives attend a series of these retreats over a period of months.

Companies that fail in phase two usually underestimate the difficulties of producing change and thus the importance of a powerful guiding coalition. Sometimes they have no history of teamwork at the top and therefore undervalue the importance of this type of coalition. Sometimes they expect the team to be led by a staff executive from human resources, quality, or strategic planning instead of a key line manager. No matter how capable or dedicated the staff head, groups without strong line leadership never achieve the power that is required.

Efforts that don't have a powerful enough guiding coalition can make apparent progress for a while. But, sooner or later, the opposition gathers itself together and stops the change.

\section{Error 3: Lacking a Vision}

In every successful transformation effort that I have seen, the guiding coalition develops a picture of the future that is relatively easy to communicate and appeals to customers, stockholders, and employees. A vision always goes beyond the numbers that are typically found in five-year plans. A vision says something that helps clarify the direction in which an organization needs to move. Sometimes the first draft comes mostly from a single individual. It is usually a bit blurry, at least initially. But after the coalition works at it for three or five or even 12 months, something much better emerges through their tough analytical thinking and a little dreaming. Eventually, a strategy for achieving that vision is also developed.

In one midsize European company, the first pass at a vision contained two-thirds of the basic ideas that were in the final product. The concept of global reach was in the initial version from the beginning. So was the idea of becoming preeminent in certain businesses. But one central idea in the final version - getting out of low value-added activities - came only after a series of discussions over a period of several months.

Without a sensible vision, a transformation effort can easily dissolve into a list of confusing and incompatible projects that can take the organization in the wrong direction or nowhere at all. Without a sound vision, the reengineering project in the accounting department, the new 360degree performance appraisal from the human resources department, the plant's quality program, the cultural change project in the sales force will not add up in a meaningful way.

In failed transformations, you often find plenty of plans, directives, and programs but no vision. In one case, a company gave out four-inch-thick notebooks describing its change effort. In mindnumbing detail, the books spelled out procedures, goals, methods, and deadlines. But nowhere was there a clear and compelling statement of where all this was leading. Not surprisingly, most of the employees with whom I talked were either confused or alienated. The big, thick books did not rally them together or inspire change. In fact, they probably had just the opposite effect. In a few of the less successful cases that I have seen, management had a sense of direction, but it was too complicated or blurry to be useful. Recently, I asked an executive in a midsize company 
to describe his vision and received in return a barely comprehensible 30-minute lecture. Buried in his answer were the basic elements of a sound vision. But they were buried-deeply.

A useful rule of thumb: If you can't communicate the vision to someone in five minutes or less and get a reaction that signifies both understanding and interest, you are not yet done with this phase of the transformation process.

\section{Error 4: Undercommunicating the Vision by a Factor of Ten}

I've seen three patterns with respect to communication, all very common. In the first, a group actually does develop a pretty good transformation vision and then proceeds to communicate it by holding a single meeting or sending out a single communication. Having used about $0.0001 \%$ of the yearly intracompany communication, the group is startled when few people seem to understand the new approach. In the second pattern, the head of the organization spends a considerable amount of time making speeches to employee groups, but most people still don't get it (not surprising, since vision captures only $0.0005 \%$ of the total yearly communication). In the third pattern, much more effort goes into newsletters and speeches, but some very visible senior executives still behave in ways that are antithetical to the vision. The net result is that cynicism among the troops goes up, while belief in the communication goes down.

Transformation is impossible unless hundreds or thousands of people are willing to help, often to the point of making short-term sacrifices. Employees will not make sacrifices, even if they are unhappy with the status quo, unless they believe that useful change is possible. Without credible communication, and a lot of it, the hearts and minds of the troops are never captured.

This fourth phase is particularly challenging if the short-term sacrifices include job losses. Gaining understanding and support is tough when downsizing is a part of the vision. For this reason, successful visions usually include new growth possibilities and the commitment to treat fairly anyone who is laid off.

Executives who communicate well incorporate messages into their hour-by-hour activities. In a routine discussion about a business problem, they talk about how proposed solutions fit (or don't fit) into the bigger picture. In a regular performance appraisal, they talk about how the employee's behavior helps or undermines the vision. In a review of a division's quarterly performance, they talk not only about the numbers but also about how the division's executives are contributing to the transformation. In a routine Q\&A with employees at a company facility, they tie their answers back to renewal goals.

In more successful transformation efforts, executives use all existing communication channels to broadcast the vision. They turn boring, unread company newsletters into lively articles about the vision. They take ritualistic, tedious quarterly management meetings and turn them into exciting discussions of the transformation. They throw out much of the company's generic management education and replace it with courses that focus on business problems and the new vision. The guiding principle is simple: Use every possible channel, especially those that are being wasted on nonessential information.

Perhaps even more important, most of the executives I have known in successful cases of major change learn to "walk the talk." They consciously attempt to become a living symbol of the new corporate culture. This is often not easy. A 60-year-old plant manager who has spent precious little time over 40 years thinking about customers will not suddenly behave in a customeroriented way. But I have witnessed just such a person change, and change a great deal. In that case, a high level of urgency helped. The fact that the man was a part of the guiding coalition and the vision-creation team also helped. So did all the communication, which kept reminding him of 
the desired behavior, and all the feedback from his peers and subordinates, which helped him see when he was not engaging in that behavior.

Communication comes in both words and deeds, and the latter are often the most powerful form. Nothing undermines change more than behavior by important individuals that is inconsistent with their words.

\section{Error 5: Not Removing Obstacles to the New Vision}

Successful transformations begin to involve large numbers of people as the process progresses. Employees are emboldened to try new approaches, to develop new ideas, and to provide leadership. The only constraint is that the actions fit within the broad parameters of the overall vision. The more people involved, the better the outcome.

To some degree, a guiding coalition empowers others to take action simply by successfully communicating the new direction. But communication is never sufficient by itself. Renewal also requires the removal of obstacles. Too often, an employee understands the new vision and wants to help make it happen, but an elephant appears to be blocking the path. In some cases, the elephant is in the person's head, and the challenge is to convince the individual that no external obstacle exists. But in most cases, the blockers are very real.

Sometimes the obstacle is the organizational structure: Narrow job categories can seriously undermine efforts to increase productivity or make it very difficult even to think about customers. Sometimes compensation or performance-appraisal systems make people choose between the new vision and their own self-interest. Perhaps worst of all are bosses who refuse to change and who make demands that are inconsistent with the overall effort.

One company began its transformation process with much publicity and actually made good progress through the fourth phase. Then the change effort ground to a halt because the officer in charge of the company's largest division was allowed to undermine most of the new initiatives. He paid lip service to the process but did not change his behavior or encourage his managers to change. He did not reward the unconventional ideas called for in the vision. He allowed human resource systems to remain intact even when they were clearly inconsistent with the new ideals. I think the officer's motives were complex. To some degree, he did not believe the company needed major change. To some degree, he felt personally threatened by all the change. To some degree, he was afraid that he could not produce both change and the expected operating profit. But despite the fact that they backed the renewal effort, the other officers did virtually nothing to stop the one blocker. Again, the reasons were complex. The company had no history of confronting problems like this. Some people were afraid of the officer. The CEO was concerned that he might lose a talented executive. The net result was disastrous. Lower-level managers concluded that senior management had lied to them about their commitment to renewal, cynicism grew, and the whole effort collapsed.

In the first half of a transformation, no organization has the momentum, power, or time to get rid of all obstacles. But the big ones must be confronted and removed. If the blocker is a person, it is important that he or she be treated fairly and in a way that is consistent with the new vision.

Action is essential, both to empower others and to maintain the credibility of the change effort as a whole. Error 6: Not Systematically Planning for, and Creating, Short-Term Wins Real transformation takes time, and a renewal effort risks losing momentum if there are no shortterm goals to meet and celebrate. Most people won't go on the long march unless they see compelling evidence in 12 to 24 months that the journey is producing expected results. Without 
short-term wins, too many people give up or actively join the ranks of those people who have been resisting change.

One to two years into a successful transformation effort, you find quality beginning to go up on certain indices or the decline in net income stopping. You find some successful new product introductions or an upward shift in market share. You find an impressive productivity improvement or a statistically higher customer satisfaction rating. But whatever the case, the win is unambiguous. The result is not just a judgment call that can be discounted by those opposing change.

Creating short-term wins is different from hoping for short-term wins. The latter is passive, the former active. In a successful transformation, managers actively look for ways to obtain clear performance improvements, establish goals in the yearly planning system, achieve the objectives, and reward the people involved with recognition, promotions, and even money. For example, the guiding coalition at a U.S. manufacturing company produced a highly visible and successful new product introduction about 20 months after the start of its renewal effort. The new product was selected about six months into the effort because it met multiple criteria: It could be designed and launched in a relatively short period, it could be handled by a small team of people who were devoted to the new vision, it had upside potential, and the new product-development team could operate outside the established departmental structure without practical problems. Little was left to chance, and the win boosted the credibility of the renewal process.

Managers often complain about being forced to produce short-term wins, but I've found that pressure can be a useful element in a change effort. When it becomes clear to people that major change will take a long time, urgency levels can drop. Commitments to produce short-term wins help keep the urgency level up and force detailed analytical thinking that can clarify or revise visions.

\section{Error 7: Declaring Victory Too Soon}

After a few years of hard work, managers may be tempted to declare victory with the first clear performance improvement. While celebrating a win is fine, declaring the war won can be catastrophic. Until changes sink deeply into a company's culture, a process that can take five to ten years, new approaches are fragile and subject to regression.

In the recent past, I have watched a dozen change efforts operate under the reengineering theme. In all but two cases, victory was declared and the expensive consultants were paid and thanked when the first major project was completed after two to three years. Within two more years, the useful changes that had been introduced slowly disappeared. In two of the ten cases, it's hard to find any trace of the reengineering work today.

Over the past 20 years, I've seen the same sort of thing happen to huge quality projects, organizational development efforts, and more. Typically, the problems start early in the process: The urgency level is not intense enough, the guiding coalition is not powerful enough, and the vision is not clear enough. But it is the premature victory celebration that kills momentum. And then the powerful forces associated with tradition take over.

Ironically, it is often a combination of change initiators and change resistors that creates the premature victory celebration. In their enthusiasm over a clear sign of progress, the initiators go overboard. They are then joined by resistors, who are quick to spot any opportunity to stop change. After the celebration is over, the resistors point to the victory as a sign that the war has been won and the troops should be sent home. Weary troops allow themselves to be convinced 
that they won. Once home, the foot soldiers are reluctant to climb back on the ships. Soon thereafter, change comes to a halt, and tradition creeps back in.

Instead of declaring victory, leaders of successful efforts use the credibility afforded by shortterm wins to tackle even bigger problems. They go after systems and structures that are not consistent with the transformation vision and have not been confronted before. They pay great attention to who is promoted, who is hired, and how people are developed. They include new reengineering projects that are even bigger in scope than the initial ones. They understand that renewal efforts take not months but years. In fact, in one of the most successful transformations that I have ever seen, we quantified the amount of change that occurred each year over a sevenyear period. On a scale of one (low) to ten (high), year one received a two, year two a four, year three a three, year four a seven, year five an eight, year six a four, and year seven a two. The peak came in year five, fully 36 months after the first set of visible wins.

\section{Error 8: Not Anchoring Changes in the Corporation's Culture}

In the final analysis, change sticks when it becomes "the way we do things around here," when it seeps into the bloodstream of the corporate body. Until new behaviors are rooted in social norms and shared values, they are subject to degradation as soon as the pressure for change is removed. Two factors are particularly important in institutionalizing change in corporate culture. The first is a conscious attempt to show people how the new approaches, behaviors, and attitudes have helped improve performance. When people are left on their own to make the connections, they sometimes create very inaccurate links. For example, because results improved while charismatic Harry was boss, the troops link his mostly idiosyncratic style with those results instead of seeing how their own improved customer service and productivity were instrumental. Helping people see the right connections requires communication. Indeed, one company was relentless, and it paid off enormously. Time was spent at every major management meeting to discuss why performance was increasing. The company newspaper ran article after article showing how changes had boosted earnings.

The second factor is taking sufficient time to make sure that the next generation of top management really does personify the new approach. If the requirements for promotion don't change, renewal rarely lasts. One bad succession decision at the top of an organization can undermine a decade of hard work. Poor succession decisions are possible when boards of directors are not an integral part of the renewal effort. In at least three instances I have seen, the champion for change was the retiring executive, and although his successor was not a resistor, he was not a change champion. Because the boards did not understand the transformations in any detail, they could not see that their choices were not good fits. The retiring executive in one case tried unsuccessfully to talk his board into a less seasoned candidate who better personified the transformation. In the other two cases, the CEOs did not resist the boards' choices, because they felt the transformation could not be undone by their successors. They were wrong. Within two years, signs of renewal began to disappear at both companies.

$\bullet \bullet$

There are still more mistakes that people make, but these eight are the big ones. I realize that in a short article everything is made to sound a bit too simplistic. In reality, even successful change efforts are messy and full of surprises. But just as a relatively simple vision is needed to guide people through a major change, so a vision of the change process can reduce the error rate. And fewer errors can spell the difference between success and failure.

Copyright (C) 2006 Harvard Business School Publishing Corporation. All rights reserved. 
Now retired, John P. Kotter was the Konosuke Matsushita Professor of Leadership at Harvard Business School in Boston. 


\section{Evaluation of Change Project using Kotter's Change Process (Post-test)}

Please describe how each stage of Kotter's Change Process might be utilized during the Change Project for Diabetes Education and Management in the clinic. An article brief by Kotter is attached for reference. Each stage is identified and then summarized. Please rate how important each stage appears to be for change to be successful on a Likert scale with 1 being particularly unimportant and 10 being extremely important. Then comment on things that might be done to fulfill each stage for the change project that is planned in the clinic.

Stage 1: Establish a Sense of Urgency. This stage includes convincing staff that continuing the current process is more dangerous than making a change.

$\begin{array}{llllllllll}1 & 2 & 3 & 4 & 5 & 6 & 7 & 8 & 9 & 10\end{array}$

Comments:

Stage 2: Form a Powerful Guiding Coalition. This stage involves assembling team members to work together toward the same goal, and choosing members who are leaders that will promote the change effort.

$\begin{array}{llllllllll}1 & 2 & 3 & 4 & 5 & 6 & 7 & 8 & 9 & 10\end{array}$

Comments:

Stage 3: Create a Vision. This stage entails presenting a vision to direct the change effort.

$\begin{array}{llllllllll}1 & 2 & 3 & 4 & 5 & 6 & 7 & 8 & 9 & 10\end{array}$

Comments:

Stage 4: Communicate the Vision. This stage requires discussion of the vision through conversation, strategies, and behaviors of the guiding coalition for the project.

$\begin{array}{llllllllll}1 & 2 & 3 & 4 & 5 & 6 & 7 & 8 & 9 & 10\end{array}$

Comments: 
Stage 5: Empower Others to Act on the Vision. This stage involves encouraging others to take risks and contribute ideas and actions to the project. Additionally, organizational structures may need to be altered if they undermine the vision.

$\begin{array}{llllllllll}1 & 2 & 3 & 4 & 5 & 6 & 7 & 8 & 9 & 10\end{array}$

Comments:

Stage 6: Plan for and Create Short-Term Wins. This stage includes defining performance improvements and recognizing those as they are accomplished by staff.

$\begin{array}{llllllllll}1 & 2 & 3 & 4 & 5 & 6 & 7 & 8 & 9 & 10\end{array}$

Comments:

Stage 7: Consolidate Improvements and Produce More Change. This stage involves making the performance improvements into more permanent structures to change the system. Implementing the vision and developing it further with offshoot projects and new ideas are part of this stage as well.

$\begin{array}{llllllllll}1 & 2 & 3 & 4 & 5 & 6 & 7 & 8 & 9 & 10\end{array}$

Comments:

Stage 8: Institutionalize the New Approaches. This stage requires recognition of the new behaviors and successes for sustainability.

$\begin{array}{llllllllll}1 & 2 & 3 & 4 & 5 & 6 & 7 & 8 & 9 & 10\end{array}$

Comments:

Reference: Kotter, J. (2006). Leading Change: Why Transformation Efforts Fail. Harvard Business Review.

The same article is attached to the post-test that was attached to the pre-test for cohesiveness. 
Appendix C

Behavior Score Dashboard Pre-test

Patient ID:

\section{Introduction}

Have you ever been diagnosed, ever been told, or have you had problems with the following? (mark all that apply)

\section{High Blood Pressure \\ High Cholesterol}

Kidney / Bladder problems

Eye or vision problems

$\square$ Frequent nausea, vomiting, constipation, diarrhea

$\square$ surgery in the last 5 years

\author{
Heart Disease / Chest Pain \\ Thyroid Disease \\ Asthma \\ $\square$ Numbness/pain/tingling of \\ hands/feet \\ Depression or anxiety
}

$\square$ Drug allergies



Other health problems
What is your height? feet inches

In the past year have you?

$\square$ Lost more than $10 \mathrm{lbs}$ Gained more than $10 \mathrm{lbs}$ Stayed about the same

During what year were you diagnosed with diabetes?

Have you had diabetes education?

Yes $\square$ No

If yes, when (month and year)?

Do you have any physical limitations that may affect your ability to perform your self-care? (check all that apply)

$\square$ Hearing problems

Vision loss (not corrected by glasses Problems with the use of your feet

How do you learn best? (check all that apply) $\square$ Listening Watching Hands On/Doing

Number of emergency room visits or 911 calls for your diabetes requiring assistance in the last three months:

Number of days missed from work, school or usual routine because of diabetes within the last 30 days:

Number of hospital admissions for diabetes within the last 3 months: 
Result of my A1C test as given to me by the health care provider:

Are you able to become pregnant? If so, when was the last time you had counseling about what to do before getting pregnant (if female and able to get pregnant)

$\square$ Never $\square$ Last 6 months $\quad \square$ Last year $\quad \square$ Over a year ago $\square$ Do not know

\section{Being Active}

Being active means you are taking part in doing things such as jogging, bicycling, golfing, gardening, or walking without stopping for at least $\mathbf{3 0}$ minutes most days of the week.

During the past week, or last 7 days, how many days were you able to be active? (circle one)

$\begin{array}{lllllll}1 & 2 & 3 & 4 & 5 & 6 & 7\end{array}$

How important is it to you to be active, where 0 is not important at all and 10 is very important?

$\begin{array}{lllllllllll}0 & 1 & 2 & 3 & 4 & 5 & 6 & 7 & 8 & 9 & 10\end{array}$

How sure are you that you can be active, where 0 is not sure at all and 10 is very sure?



\section{Healthy Eating}

Following an eating plan that is good for you includes: not eating too much, counting the amount of carbohydrates you eat, not eating too much fat, keeping an eye on and/or drinking less alcohol. It also means eating fruits, vegetables, whole grains, and beans and other foods with high fiber. Following an eating plan that is good for you may also include reaching goals for losing weight, and limiting the amount of protein and salt you eat.

During the past week, or last 7 days, how many days were you able to follow a healthy eating plan? (circle one)

$$
\begin{array}{lllllll}
1 & 2 & 3 & 4 & 5 & 6 & 7
\end{array}
$$

How sure are you that you can follow an eating plan that is good for you, where 0 is not sure at all and 10 is very sure? (circle one)

$\begin{array}{lllllllllll}0 & 1 & 2 & 3 & 4 & 5 & 6 & 7 & 8 & 9 & 10\end{array}$

How important is it to you to follow an eating plan that is good for you, where 0 is not important at all and 10 is very important? (circle one)

$\begin{array}{lllllllllll}0 & 1 & 2 & 3 & 4 & 5 & 6 & 7 & 8 & 9 & 10\end{array}$


Having diabetes means that you need to make choices about food, physical activity, and when and how to take medicines. You may need blood tests and other exams to monitor your diabetes health status. You also need to do things to prevent problems related to your health, know how to cope with your diabetes, and make everyday management decisions.

The following questions are about the things you need to do to stay healthy with your diabetes. These questions ask about the things you do, how often you do them, how important they are to you and how sure you are about doing them.

\section{Reducing Risks}

Reducing risks means that you are taking steps to prevent or reduce problems related to diabetes. This includes having eyes checked by an eye doctor, having feet checked by a health care provider, seeing a dentist, getting flu and/or pneumonia vaccinations, having blood pressure checked, having cholesterol and triglycerides checked, and not smoking.

Check all of the following things that have happened in the past year.

\begin{tabular}{|l|l|}
\hline & Had an eye exam (with drops in the eyes) by an eye doctor. \\
\hline & Had feet checked by a health care provider. \\
\hline & Saw a dentist. \\
\hline & Had a flu and/or pneumonia vaccination. \\
\hline & Had blood pressure checked. \\
\hline & Had cholesterol and triglycerides checked. \\
\hline & Got help to stop smoking (only applicable for smokers) \\
\hline & Had an A1C test \\
\hline
\end{tabular}

How important do you feel it is to do the things listed above to help prevent or reduce problems related to diabetes, where 0 is not important at all and 10 is very important?

$\begin{array}{lllllllllll}0 & 1 & 2 & 3 & 4 & 5 & 6 & 7 & 8 & 9 & 10\end{array}$

How often does life stress make it hard for you to perform diabetes self care, where 0 is not at all and 10 is very likely?

$\begin{array}{lllllllllll}0 & 1 & 2 & 3 & 4 & 5 & 6 & 7 & 8 & 9 & 10\end{array}$

How often do you closely examine or look at your feet with your socks off?

Daily $\square$ Several times a week $\square$ A few times a month

Once in a while $\quad \square$ Rarely or never

How sure are you that you can get the help you need to prevent or reduce problems related to diabetes, where 0 is not sure at all and 10 is very sure?

$\begin{array}{llllllllll}0 & 1 & 2 & 3 & 4 & 5 & 6 & 7 & 8 & 9\end{array}$


Taking Medication

Taking medication means that you take medicines that have been prescribed by your healthcare provider to treat your diabetes or other health conditions. These may be pills, insulin, creams, or other medicines that you inject. For the next several questions, please answer for all the medicines that you take.

Do you take diabetes medication? Check all that apply

Do not take medication

Other injections for blood sugar

Pills

Insulin

Do you take any additional nutritional suppliements? Check all that apply
Vitamins
Herbal supplements
Other

Sometimes it can be a hard to remember to take all of your medicines. Over the past week, or last 7 days, how many days have you missed taking your diabetes medicines as recommended?

$\begin{array}{lllllll}1 & 2 & 3 & 4 & 5 & 6 & 7\end{array}$

How important is it to you to take your medicines, where 0 is not important at all and 10 is very important?
0
1
23
45
6
7
89
10

How sure are you that you can take your medicines, where 0 is not sure at all and 10 is very sure?

$\begin{array}{llllllllll}0 & 1 & 2 & 3 & 4 & 5 & 6 & 7 & 8 & 9\end{array}$

\title{
Monitoring
}

Monitoring for people with diabetes means that they regularly check blood sugar. Monitoring also includes checking your blood pressure, cholesterol, and weight. For this set of questions, we will focus on blood sugar monitoring. Monitoring the level of your blood sugar means that you use a blood sugar meter to take a blood sugar reading. Monitoring may be done on your own or with the help of a health care provider.

During the past week, or last 7 days, how many days were you able to monitor your blood sugar at least once per day?

$\begin{array}{lllllll}1 & 2 & 3 & 4 & 5 & 6 & 7\end{array}$

How important is it to you to monitor your blood sugar at least once per day, where 0 is not important at all and 10 is very important?
0
123
45
67
8
910

How sure are you that you can monitor your blood sugar at least once per day, where 0 is not sure at all and 10 is very sure?

0

1

2

3

\begin{abstract}
4
\end{abstract}

5

6

7

8

9

10 
How often do you have high blood sugar?
$\square$ Daily
$\square$ Several times a week
A few times a month
Once in a while
Rarely or never
Don't know
How often do you have low blood sugar?
Daily
Several times a week
A few times a month
Once in a while
Rarely or never
Don't know

Do you wear a bracelet or keep something with you to identify that you have diabetes?

$\square$ Yes $\square$ No

Do you use a meter to check your blood sugar? (check one) $\quad \square$ Yes $\quad \square$ No

How often do you usually check your blood sugar?
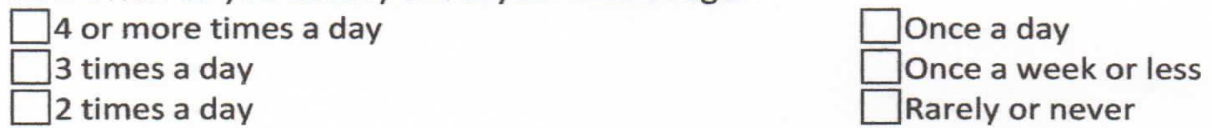

\section{Problem Solving}

Problem solving means coming up with ways to make everyday and/or challenging decisions to stay healthy with your diabetes. When you make a decision about what to eat or how much to eat, choose which medicines to take, decide whether to take a walk, or determine how you're going to make changes to your daily routine to help your diabetes, you are problem solving. For most situations this means figuring out the problem, finding a way to deal with it and thinking about what may prevent you from solving the problem.

Over the past week, or last 7 days, how many days have you done problem solving for everyday and/or challenging decisions?

$\begin{array}{lllllll}1 & 2 & 3 & 4 & 5 & 6 & 7\end{array}$

How important is being able to problem solve when being faced with everyday and/or challenging decisions, where 0 is not important at all and 10 is very important?
0
1
23
45
67
8
$9 \quad 10$

How sure are you that you can problem solve when faced with everyday and/or challenging decisions, where 0 is not sure at all and 10 is very sure?
0
1
2
3
45
6
7
8
9
10

When you are sick or can't eat your usual foods how often do you do the following? (check all that apply)

$\square$ Replace usual food with carbohydrates or sugar

Take diabetes medication

Drink more water

Check ketone level 
Check blood sugar more often

Do nothing
Contact health care provider

Other

\section{Healthy Coping}

Healthy coping is having ways to help yourself or knowing when and how to seek help when you are overwhelmed by your diabetes. Every person with diabetes has to deal with stress, strong emotions or family situations that can make it hard to manage their diabetes. How you feel and your quality of life can be affected by emotional and social problems.

Over the past week, or last 7 days, how many days were you able to cope in a healthy way when you faced stress, emotional or family problems?

$\begin{array}{lllllll}1 & 2 & 3 & 4 & 5 & 6 & 7\end{array}$

How important is it to you to either help yourself or know when and how to seek help when you are faced with stress, emotional or family problems, where 0 is not important at all and 10 is very important?
0
1
23
4
5
6
$7 \quad 8$
$9 \quad 10$

How sure are you that you can help yourself or know when and how to seek help when faced with stress, emotional or family problems, where 0 is not sure at all and 10 is very sure?
0
123
45
67
8
$9 \quad 10$

How often do you feel depressed?

$\square$ A lot

$\square$ Some

$\square$ A little

Not at all

How much does your diabetes interfere with sexual function?
$\square$ A lot
Some
A little
$\square$ Not at all

\section{Goal Setting}

Having diabetes means you may need to make changes. What changes, if any, would you like to make now?

$\square$ Activity
$\square$ Medication taking
$\square$ Problem solving for blood sugars and sick days
$\square \quad$ Living with diabetes

\section{Culture}

Do you have any cultural factors that may make it more difficult for you to control your diabetes?

If yes, please state what these are: 
Do you have trouble paying for your medications or doctor visits?

$\square$ Yes

$\square$ No

If yes, please explain what kind of trouble

Do you have a support person at home?

$\square$ Yes

No 


\section{Behavior Score Dashboard Post-test}

Patient ID:

What is your height? feet inches

Have there been any change(s) in the following health history areas? If there have been no changes, check here $\square$

$\square$ High Blood Pressure

High Cholesterol

$\square$ Kidney / Bladder problems

$\square$ Eye or vision problems

$\square$ Frequent nausea, vomiting, constipation, diarrhea

$\square$ Surgery in the last 5 years $\square$ Heart Disease / Chest Pain

$\square$ Thyroid Disease

Asthma

$\square$ Numbness/pain/tingling of hands/feet

$\square$ Depression or anxiety

$\square$ Drug allergies
What is your current weight? lbs

Number of emergency room visits or 911 calls for your diabetes requiring assistance in the last three months:

Number of days missed from work, school or usual routine because of diabetes within the last 30 days:

Number of hospital admissions for diabetes within the last 3 months: 
Having diabetes means that you need to make choices about food, physical activity, and when and how to take medicines. You may need blood tests and other exams to monitor your diabetes health status. You also need to do things to prevent problems related to your health, know how to cope with your diabetes, and make everyday management decisions.

The following questions are about the things you need to do to stay healthy with your diabetes. These questions ask about the things you do, how often you do them, how important they are to you and how sure you are about doing them.

\section{Reducing Risks}

Reducing risks means that you are taking steps to prevent or reduce problems related to diabetes. This includes having eyes checked by an eye doctor, having feet checked by a health care provider, seeing a dentist, getting flu and/or pneumonia vaccinations, having blood pressure checked, having cholesterol and triglycerides checked, and not smoking.

Check all of the following things that have happened in the past year.

\begin{tabular}{|l|l|}
\hline & Had an eye exam (with drops in the eyes) by an eye doctor. \\
\hline & Had feet checked by a health care provider. \\
\hline & Saw a dentist. \\
\hline & Had a flu and/or pneumonia vaccination. \\
\hline & Had blood pressure checked. \\
\hline & Had cholesterol and triglycerides checked. \\
\hline & Got help to stop smoking (only applicable for smokers) \\
\hline & Had an A1C test \\
\hline
\end{tabular}

How important do you feel it is to do the things listed above to help prevent or reduce problems related to diabetes, where 0 is not important at all and 10 is very important?

$\begin{array}{lllllllllll}0 & 1 & 2 & 3 & 4 & 5 & 6 & 7 & 8 & 9 & 10\end{array}$

How often does life stress make it hard for you to perform diabetes self-care, where 0 is not at all and 10 is very likely?
0
1
2
34
$5 \quad 6 \quad 7$
89
10

How sure are you that you can get the help you need to prevent or reduce problems related to diabetes, where 0 is not sure at all and 10 is very sure?

$\begin{array}{lllllllllll}0 & 1 & 2 & 3 & 4 & 5 & 6 & 7 & 8 & 9 & 10\end{array}$

Result of my $\mathrm{A} 1 \mathrm{C}$ test as given to me by the health care provider: 


\section{Being Active}

Being active means you are taking part in doing things such as jogging, bicycling, golfing, gardening, or walking without stopping for at least $\mathbf{3 0}$ minutes most days of the week.

During the past week, or last 7 days, how many days were you able to be active? (circle one)

$$
\begin{array}{lllllll}
1 & 2 & 3 & 4 & 5 & 6 & 7
\end{array}
$$

How important is it to you to be active, where 0 is not important at all and 10 is very important?

$\begin{array}{lllllllllll}0 & 1 & 2 & 3 & 4 & 5 & 6 & 7 & 8 & 9 & 10\end{array}$

How sure are you that you can be active, where 0 is not sure at all and 10 is very sure?

$\begin{array}{lllllllllll}0 & 1 & 2 & 3 & 4 & 5 & 6 & 7 & 8 & 9 & 10\end{array}$

Healthy Eating

Following an eating plan that is good for you includes: not eating too much, counting the amount of carbohydrates you eat, not eating too much fat, keeping an eye on and/or drinking less alcohol. It also means eating fruits, vegetables, whole grains, and beans and other foods with high fiber. Following an eating plan that is good for you may also include reaching goals for losing weight, and limiting the amount of protein and salt you eat.

During the past week, or last 7 days, how many days were you able to follow a healthy eating plan? (circle one)
1
2
3
4
5
6
7

How sure are you that you can follow an eating plan that is good for you, where 0 is not sure at all and 10 is very sure? (circle one)

$\begin{array}{lllllllllll}0 & 1 & 2 & 3 & 4 & 5 & 6 & 7 & 8 & 9 & 10\end{array}$

How important is it to you to follow an eating plan that is good for you, where 0 is not important at all and 10 is very important? (circle one)
0
12
3
4
5
6
7
89
10

Taking Medication

Taking medication means that you take medicines that have been prescribed by your healthcare provider to treat your diabetes or other health conditions. These may be pills, insulin, creams, or other medicines that you inject. For the next several questions, please answer for all the medicines that you take.

Do you take diabetes medication? Check all that apply

Do not take medication

Pills

Other injections for blood sugar

Insulin 
Have there been any changes to your medication dosages since your last diabetes education session? $\square$ Yes $\square$ No

Have there been any changes to your medications frequency since your last diabetes education session? $\square$ Yes $\square$ No

Have you stopped taking any medications since your last diabetes education session? $\square$ Yes $\square$ No

Sometimes it can be a hard to remember to take all of your medicines. Over the past week, or last 7 days, how many days have you missed taking your diabetes medicines as recommended?
2
3
45
6
7

How important is it to you to take your medicines, where 0 is not important at all and 10 is very important?

$\begin{array}{lllllllllll}0 & 1 & 2 & 3 & 4 & 5 & 6 & 7 & 8 & 9 & 10\end{array}$

How sure are you that you can take your medicines, where 0 is not sure at all and 10 is very sure?
0
1
2
3
4
56
7
$8 \quad 9 \quad 10$

\section{Monitoring}

Monitoring for people with diabetes means that they regularly check blood sugar. Monitoring also includes checking your blood pressure, cholesterol, and weight. For this set of questions, we will focus on blood sugar monitoring. Monitoring the level of your blood sugar means that you use a blood sugar meter to take a blood sugar reading. Monitoring may be done on your own or with the help of a health care provider.

During the past week, or last 7 days, how many days were you able to monitor your blood sugar at least once per day?

$\begin{array}{lllllll}1 & 2 & 3 & 4 & 5 & 6 & 7\end{array}$

How important is it to you to monitor your blood sugar at least once per day, where 0 is not important at all and 10 is very important?
0
12
3
4
5
67
$\begin{array}{lll}8 & 9 & 10\end{array}$

How sure are you that you can monitor your blood sugar at least once per day, where 0 is not sure at all and 10 is very sure?

$\begin{array}{lllllllllll}0 & 1 & 2 & 3 & 4 & 5 & 6 & 7 & 8 & 9 & 10\end{array}$

How often do you have high blood sugar?

Daily

Once in a while
Several times a week

Rarely or never
A few times a month

Don't know 
How often do you have low blood sugar?

$\begin{array}{lll}\square \text { Daily } & \square \text { Several times a week } \\ \square \text { Once in a while } \quad \square \text { Rarely or never } & \square \text { Don't know times a month } \\ & & \\ \text { How often do you usually check your blood sugar? } & \\ \square \text { 4 or more times a day } & \\ \square \text { 3 times a day } & & \square \text { Once a day } \\ \square \text { 2 times a day } & & \text { Rarely or never }\end{array}$

\section{Problem Solving}

Problem solving means coming up with ways to make everyday and/or challenging decisions to stay healthy with your diabetes. When you make a decision about what to eat or how much to eat, choose which medicines to take, decide whether to take a walk, or determine how you're going to make changes to your daily routine to help your diabetes, you are problem solving. For most situations this means figuring out the problem, finding a way to deal with it and thinking about what may prevent you from solving the problem.

Over the past week, or last 7 days, how many days have you done problem solving for everyday and/or challenging decisions?
1
23
4
5
6
7

How important is being able to problem solve when being faced with everyday and/or challenging decisions, where 0 is not important at all and 10 is very important?

$\begin{array}{llllllllll}0 & 1 & 2 & 3 & 4 & 5 & 6 & 7 & 8 & 9\end{array}$

How sure are you that you can problem solve when faced with everyday and/or challenging decisions, where 0 is not sure at all and 10 is very sure?
0
1
2
3
4
56
7
8
9
10

Healthy Coping

Healthy coping is having ways to help yourself or knowing when and how to seek help when you are overwhelmed by your diabetes. Every person with diabetes has to deal with stress, strong emotions or family situations that can make it hard to manage their diabetes. How you feel and your quality of life can be affected by emotional and social problems.

Over the past week, or last 7 days, how many days were you able to cope in a healthy way when you faced stress, emotional or family problems?

1

2

3

4

5

6 
How important is it to you to either help yourself or know when and how to seek help when you are faced with stress, emotional or family problems, where 0 is not important at all and 10 is very important?

$\begin{array}{lllllllllll}0 & 1 & 2 & 3 & 4 & 5 & 6 & 7 & 8 & 9 & 10\end{array}$

How sure are you that you can help yourself or know when and how to seek help when faced with stress, emotional or family problems, where 0 is not sure at all and 10 is very sure?

$\begin{array}{lllllllllll}0 & 1 & 2 & 3 & 4 & 5 & 6 & 7 & 8 & 9 & 10\end{array}$

How often do you feel depressed?

A lot

Some

A little

Not at all 


\section{Appendix D}

\section{Diabetes Demographic Data Collection Tool}

\section{Time one PREVIOUS TO INTERVENTION}

Age

Gender: $\mathrm{M}$ or $\mathrm{F}$

Ethnicity: White African-American Asian Hispanic Native American Other

Marital Status: Single Married Divorced Separated Widowed Significant other

Education Level: less than high school GED graduated high school some college college graduate master's degree doctorate

Zip code (to calculate miles from residence):

Duration of diabetes:

PHQ-9 Depression Score:

Amount of Physical Activity per day/week in minutes

Number of Co-morbidities:

Body Weight:

BMI:

HgA1C:

Random blood glucose:

Serum Creatinine:

Urine Micro-albumin/Creatinine Ratio:

Blood Pressure:

Serum Lipids

TC:

HDL:

LDL:

Trig: 
Diabetes Demographic Data Collection Tool

\section{Time two AFTER INTERVENTION}

PHQ-9 Depression Score:

Amount of Physical Activity per day/week in minutes

Body Weight:

BMI:

HgA1C:

Fasting blood glucose:

Serum Creatinine:

Urine Micro-albumin/Creatinine Ratio:

Blood Pressure:

Serum Lipids

TC:

HDL:

LDL:

Trig: 


\section{Appendix E}

\section{Capstone Project Flowsheet}

\begin{tabular}{|c|c|c|c|c|c|c|c|}
\hline Date & $\begin{array}{l}\text { Day/Time } \\
\text { of Call }\end{array}$ & $\begin{array}{l}\text { Able } \\
\text { to } \\
\text { speak } \\
\text { with } \\
\text { pt.? } \\
\text { Y/N }\end{array}$ & $\begin{array}{l}\text { Amount of } \\
\text { total time } \\
\text { spent on } \\
\text { this call }\end{array}$ & $\begin{array}{l}\text { Education reviewed? } \\
\text { Y/N; Comments }\end{array}$ & $\begin{array}{l}\text { Fingerstick } \\
\text { Average } \\
\text { Fasting (F)? } \\
2 \text { hrs. Post- } \\
\text { Prandial } \\
(\mathrm{PP}) ?\end{array}$ & Patient Questions, Concerns & Topics discussed \\
\hline & & & & & & & \\
\hline & & & & & & & \\
\hline & & & & & & & \\
\hline & & & & & & & \\
\hline & & & & & & & \\
\hline & & & & & & & \\
\hline & & & & & & & \\
\hline & & & & & & & \\
\hline & & & & & & & \\
\hline
\end{tabular}

Patient ID: 


\section{Appendix F}

AADE7 Self-Care Behaviors and Goals Telephone Guide to Weekly Calls (Highlights are AADE7 guidelines)

\begin{tabular}{|c|c|}
\hline $\begin{array}{c}\text { AADE7 Self-Care Behaviors } \\
\text { Weekly Design (as formulated by Investigators) }\end{array}$ & $\begin{array}{c}\text { Discussion Questions and Talking Points to } \\
\text { Relate to each Behavior (formulated by } \\
\text { Investigators): }\end{array}$ \\
\hline \multicolumn{2}{|l|}{ 1. Taking Medication } \\
\hline $\begin{array}{l}\text { Goals } \\
\text { - Increase taking medications on time } \\
\text { - Miss fewer medications } \\
\text { - Take medications as prescribed }\end{array}$ & $\begin{array}{l}\text { - How often do you miss medications? } \\
\text { Why? } \\
\text { Do you feel that all of the medications } \\
\text { that you take are necessary? }\end{array}$ \\
\hline \multicolumn{2}{|l|}{ 2. Monitoring } \\
\hline $\begin{array}{cl}\text { Goals } & \\
\text { - Follow monitoring schedule } \\
\text { - Monitor more often } \\
\text { - Monitor health status }\end{array}$ & $\begin{array}{l}\text { Do you see benefits to checking your } \\
\text { sugar regularly? If so, what? } \\
\text { - Check when feeling unwell or in at-risk } \\
\text { situations } \\
\text { - Document blood glucose logs } \\
\text { Do you have adequate glucose } \\
\text { monitoring supplies and are you } \\
\text { comfortable using? } \\
\text { What are the primary obstacles that keep } \\
\text { you from checking your sugar? }\end{array}$ \\
\hline \multicolumn{2}{|l|}{ 3. Healthy Eating } \\
\hline $\begin{array}{l}\text { Goals } \\
\text { - Make better food choices } \\
\text { - Reduce portion size } \\
\text { - Follow meal plan }\end{array}$ & $\begin{array}{l}\text { - What are your favorite foods? } \\
\text { - Discuss starch/CHO \& calorie intake, } \\
\text { portion size } \\
\text { - What do you see as the primary obstacle } \\
\text { to eating healthy? }\end{array}$ \\
\hline 4. Being Active & \\
\hline
\end{tabular}




\begin{tabular}{|c|c|}
\hline $\begin{array}{cl}\text { Goals } & \\
\text { - Exercise longer } \\
\text { - Exercise more often } \\
\text { - Follow exercise plan }\end{array}$ & $\begin{array}{l}\text { - Do you like to exercise? } \\
\text { - What do you see as the primary obstacle } \\
\text { to exercising? } \\
\text { Discuss exercise plans, including even } 10 \\
\text { minute intervals, to total of } 30 \text { minutes } 5 \text { - } \\
\text { days per week; discuss types of } \\
\text { and weight training }\end{array}$ \\
\hline \multicolumn{2}{|l|}{ 5. Problem Solving } \\
\hline $\begin{array}{cl}\text { Goals } & \\
\text { - Identify potential problems } \\
\text { - Plan problem situation treatment } \\
\text { - Prevent problem situations }\end{array}$ & $\begin{array}{l}\text { What problems do you have managing } \\
\text { your diabetes? } \\
\text { - What are some strategies that you might } \\
\text { use to tackle problems? }\end{array}$ \\
\hline \multicolumn{2}{|l|}{ 6. Healthy Coping } \\
\hline $\begin{array}{l}\text { Goals } \\
\text { - Cope with diagnosis of disease } \\
\text { - Adapt to lifestyle changes } \\
\text { - Get support from family/friends }\end{array}$ & $\begin{array}{l}\text { - Do you have a good support system? } \\
\text { - How has having diabetes changed your } \\
\text { life? } \\
\text { - Have you considered attending the local } \\
\text { diabetes support group? } \\
\text { - Review PHQ-9 question/answers }\end{array}$ \\
\hline \multicolumn{2}{|l|}{ 7. Reducing Risks } \\
\hline $\begin{array}{cl}\text { Goals } & \\
\text { - Stop smoking } \\
\text { - Get health checkups } \\
\text { - Perform daily self-care activities }\end{array}$ & $\begin{array}{l}\text { - What complications of diabetes are you } \\
\text { aware of? } \\
\text { - What are some daily self-care activities } \\
\text { that you can do to prevent complications? }\end{array}$ \\
\hline
\end{tabular}




\section{Appendix G}

\section{SMART WorkPlan}

Project Goals: The overall goal is to change the current education and management for patients with diabetes by using a telemonitoring intervention to educate and manage diabetes for improved glycemic control.

\begin{tabular}{|c|c|c|c|c|c|}
\hline *SMART Objective & Activities & $\begin{array}{l}\text { Projected } \\
\text { Completion } \\
\text { Date }\end{array}$ & $\begin{array}{l}\text { Projected } \\
\text { Number of } \\
\text { People Reached }\end{array}$ & $\begin{array}{l}\text { Organization(s)/ } \\
\text { Partner(s) } \\
\text { collaborating with } \\
\text { to conduct activity }\end{array}$ & $\begin{array}{l}\text { Evaluation Plan (Describe } \\
\text { measures used to assess } \\
\text { satisfaction, project } \\
\text { outcomes, benefits of } \\
\text { activities, etc.) }\end{array}$ \\
\hline $\begin{array}{l}\text { Apply immediately for } \\
\text { IRB approval through } \\
\text { WVU }\end{array}$ & $\begin{array}{l}\text { *Review proposal with } \\
\text { Capstone Chair for } \\
\text { recommendations } \\
\text { *Complete IRB protocol and } \\
\text { submit to IRB }\end{array}$ & $\begin{array}{l}\text { September } \\
2013\end{array}$ & 5 & $\begin{array}{l}\text { Capstone } \\
\text { Chair/Committee; } \\
\text { WVU }\end{array}$ & $\begin{array}{l}\text { Await IRB approval and } \\
\text { recommendations }\end{array}$ \\
\hline $\begin{array}{l}\text { In September } 2013 \text { the } \\
\text { staff of the Preston } \\
\text { Clinic will meet and } \\
\text { review project }\end{array}$ & $\begin{array}{l}\text { *Review intake criteria for } \\
\text { diabetes patients to be } \\
\text { enrolled in the project } \\
\text { *Identify stakeholders for } \\
\text { staff } \\
\text { *Identify change champion } \\
\text { and project manager for staff } \\
\text { *Incorporate Kotter's change } \\
\text { theory into the change } \\
\text { process }\end{array}$ & $\begin{array}{l}\text { September } \\
15,2013\end{array}$ & 15 & $\begin{array}{l}\text { Preston Urgent Care } \\
\text { Family Practice, } \\
\text { LLC.; Capstone } \\
\text { Chair/Committee }\end{array}$ & Finalize project details \\
\hline $\begin{array}{l}\text { In September } 2013 \text { the } \\
\text { project manager will } \\
\text { finalize all patient } \\
\text { handouts and computer }\end{array}$ & $\begin{array}{l}\text { * Patient handouts will be } \\
\text { developed and completed } \\
\text { *Booklets will be chosen and } \\
\text { all information compiled into }\end{array}$ & $\begin{array}{l}\text { September } \\
15,2013\end{array}$ & 15 & $\begin{array}{l}\text { Preston Urgent Care } \\
\text { Family Practice, } \\
\text { LLC.; Capstone } \\
\text { Chair/Committee }\end{array}$ & $\begin{array}{l}\text { All tools to be utilized will } \\
\text { be finalized }\end{array}$ \\
\hline
\end{tabular}




\begin{tabular}{|c|c|c|c|c|c|}
\hline tools & $\begin{array}{l}\text { enrollment packets } \\
\text { *An outline with patient } \\
\text { information, description of } \\
\text { project and timeline will be } \\
\text { developed } \\
\text { *Computer template for } \\
\text { telephone visits will be } \\
\text { developed and completed } \\
\text { *Computer tracking for } \\
\text { auditing will be implemented } \\
\text { *Familiarize staff with tools }\end{array}$ & & & & \\
\hline $\begin{array}{l}\text { By September } 2013 \text { the } \\
\text { contract will be finalized } \\
\text { with the clinic. The } \\
\text { contract will contain an } \\
\text { outline of the project and } \\
\text { be officially signed to } \\
\text { indicate administrative } \\
\text { approval }\end{array}$ & $\begin{array}{l}* \text { Develop and complete } \\
\text { contract } \\
* \text { Meet in person with the } \\
\text { administrator for contract } \\
\text { negotiations and completion } \\
\text { of final contract with signing }\end{array}$ & $\begin{array}{l}\text { September } \\
30,2013\end{array}$ & 1 & $\begin{array}{l}\text { Preston Urgent Care } \\
\text { Family Practice, } \\
\text { LLC.; Capstone } \\
\text { Chair/Committee }\end{array}$ & $\begin{array}{l}\text { Complete contract } \\
\text { negotiations and formalize } \\
\text { final contract } \\
\text { Obtain signed contract with } \\
\text { project outline }\end{array}$ \\
\hline $\begin{array}{l}\text { By November } 30,2013 \text {, } \\
\text { all } 10 \text { patients will be } \\
\text { enrolled }\end{array}$ & $\begin{array}{l}\text { *Work with Preston clinic } \\
\text { staff to identify and enroll } \\
\text { patients into project } \\
\text { *Baseline fingersticks will } \\
\text { be identified and recorded } \\
\text { for all patients enrolled } \\
\text { *A1C baseline will be } \\
\text { identified as part of } \\
\text { enrollment criteria }\end{array}$ & $\begin{array}{l}\text { November } \\
30,2013\end{array}$ & 10 & $\begin{array}{l}\text { Preston Urgent Care } \\
\text { Family Practice, } \\
\text { LLC.; Capstone } \\
\text { Chair/Committee }\end{array}$ & Project enrollment \\
\hline $\begin{array}{l}\text { By December } 15,2013, \\
\text { all patients will have at } \\
\text { least one diabetes phone }\end{array}$ & $\begin{array}{l}* \text { Weekly telephone calls for } \\
\text { diabetes education and } \\
\text { management }\end{array}$ & $\begin{array}{l}\text { December } \\
15,2013\end{array}$ & 10 & $\begin{array}{l}\text { Preston Urgent Care } \\
\text { Family Practice, } \\
\text { LLC.; Capstone }\end{array}$ & Blood glucose log evaluation \\
\hline
\end{tabular}




\begin{tabular}{|c|c|c|c|c|c|}
\hline $\begin{array}{l}\text { call visit and a review of } \\
\text { glucose measurement }\end{array}$ & & & & Chair/Committee & \\
\hline $\begin{array}{l}\text { By December 15, 2013, } \\
\text { review the } \\
\text { implementation of the } \\
\text { clinical project }\end{array}$ & $\begin{array}{l}\text { *Identify how the change } \\
\text { process steps have been } \\
\text { integrated into the project } \\
\text { and their effectiveness at } \\
\text { guiding change in clinic }\end{array}$ & $\begin{array}{l}\text { December } \\
15,2013\end{array}$ & & $\begin{array}{l}\text { Preston Urgent Care } \\
\text { Family Practice, } \\
\text { LLC.; Capstone } \\
\text { Chair }\end{array}$ & $\begin{array}{l}\text { Review use of educational } \\
\text { materials, flowsheets used, } \\
\text { and implementation methods } \\
\text { being used }\end{array}$ \\
\hline $\begin{array}{l}\text { By March } 15,2014, \text { all } \\
\text { patients will have at least } \\
\text { one follow up diabetes } \\
\text { clinic visit and an A1C } \\
\text { measurement }\end{array}$ & $\begin{array}{l}* \text { Weekly telephone calls for } \\
\text { diabetes education and } \\
\text { management } \\
\text { *In office visit after three } \\
\text { months in the project to } \\
\text { continue for duration of } \\
\text { project as per usual standard } \\
\text { of care }\end{array}$ & $\begin{array}{l}\text { March 15, } \\
2014\end{array}$ & 10 & $\begin{array}{l}\text { Preston Urgent Care } \\
\text { Family Practice, } \\
\text { LLC.; Capstone } \\
\text { Chair/Committee }\end{array}$ & $\begin{array}{l}\text { A1C and blood glucose log } \\
\text { evaluation }\end{array}$ \\
\hline $\begin{array}{l}\text { In March 2014, measure } \\
\text { post-change }\end{array}$ & $\begin{array}{l}\text { Provider Post-change } \\
\text { environment }\end{array}$ & March, 2014 & 4 (providers) & $\begin{array}{l}\text { Preston Urgent Care } \\
\text { Family Practice, } \\
\text { LLC. }\end{array}$ & $\begin{array}{l}\text { Provider survey and } \\
\text { feedback on project }\end{array}$ \\
\hline $\begin{array}{l}\text { By March } 15,2014 \text { the } \\
\text { patients will complete } \\
\text { the project intervention }\end{array}$ & $\begin{array}{l}\text { * Weekly telephone calls for } \\
\text { diabetes education and } \\
\text { management } \\
\text { *Participant evaluations of } \\
\text { the program } \\
\text { *Evaluate educational } \\
\text { materials used, timeline and } \\
\text { framework of project, } \\
\text { process evaluation } \\
\text { *Identify statistically } \\
\text { significant } \\
\text { changes/improvement in } \\
\text { glycemic control and "what } \\
\text { worked" for patients for }\end{array}$ & $\begin{array}{l}\text { March 15, } \\
2014\end{array}$ & 10 & $\begin{array}{l}\text { Preston Urgent Care } \\
\text { Family Practice, } \\
\text { LLC.; Capstone } \\
\text { Chair/Committee }\end{array}$ & $\begin{array}{l}\text { Participant evaluation of } \\
\text { program } \\
\text { A1C and blood glucose log } \\
\text { evaluation }\end{array}$ \\
\hline
\end{tabular}




\begin{tabular}{|l|l|l|l|l|}
\hline & $\begin{array}{l}\text { education and management } \\
\text { *Create and deliver a survey } \\
\text { for patients to complete an } \\
\text { evaluation of the project }\end{array}$ & & \\
\hline $\begin{array}{l}\text { By March 31, 2014, } \\
\text { complete analysis of } \\
\text { project and capstone }\end{array}$ & $\begin{array}{l}\text { * Analyze data } \\
\text { * Write up final capstone } \\
\text { paper }\end{array}$ & $\begin{array}{l}\text { March 31, } \\
2014\end{array}$ & $\begin{array}{l}20 \text { (10 patients } \\
\text { and 10 staff) }\end{array}$ & $\begin{array}{l}\text { Preston Urgent Care } \\
\text { Family Practice, } \\
\text { LLC.; Capstone } \\
\text { Chair/Committee }\end{array}$ \\
\hline
\end{tabular}

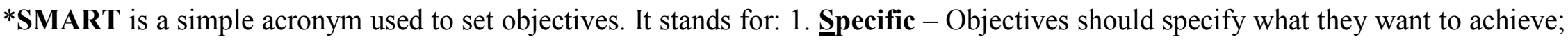
2. Measurable - You should be able to measure if you are meeting the objectives or not; 3 . Achievable - Are the objectives you set, achievable and attainable; 4 . Realistic - Can you realistically achieve the objectives with the resources you have; and 5 . Time - When do you want to achieve the set objectives. 


\section{Appendix H}

\section{Capstone Budget Plan Form and Justification}

List funds requested for each category including a reasonable justification for expenses.

\begin{tabular}{|c|c|c|}
\hline Budget Categories & Personal Funds & Organizational Contributions \\
\hline ADMINISTRATIVE COSTS & $\$ 0$ & $\$ 2160$ \\
\hline \multicolumn{3}{|c|}{$\begin{array}{l}\text { Administrative justification: In order to provide thorough education and management for the total number of } 10 \\
\text { patients with diabetes over the course of the project, a nurse practitioner will be needed for } 4 \text { hours per week for } \\
\text { approximately } 3 \text { months. The amount noted above will cover salary but no fringe benefits. The work involved includes: } \\
\text { project staff to plan, develop and implement the telemonitoring education program. This staff will also see the patients in } \\
\text { their usual care clinic visits and provide telephone interventions during usual staff hours when possible. Hence, the salary } \\
\text { will be met by the clinic as an organizational contribution. } \\
\text { An average Nurse practitioner salary } \$ 45 / \mathrm{hr} \times \mathrm{x} 4 \mathrm{hr} / \mathrm{wk} \text {. } \mathrm{x} 12 \text { weeks }=\$ 2160\end{array}$} \\
\hline MARKETING & $\$ 0$ & $\$ 0$ \\
\hline \multicolumn{3}{|c|}{ Marketing justification: No marketing plans at this time other than briefing at the clinic. } \\
\hline $\begin{array}{l}\text { EDUCATIONAL } \\
\text { MATERIALS/ INCENTIVES }\end{array}$ & $\$ 50$ & $\$ 50$ \\
\hline \multicolumn{3}{|c|}{$\begin{array}{l}\text { Educational Materials/Incentives justification: Educational handouts of choice from ADA (including printout costs } \\
\text { to be done in the clinic) } \$ 50\end{array}$} \\
\hline $\begin{array}{l}\text { HOSPITALITY (food, room } \\
\text { rentals, etc.) }\end{array}$ & $\$ 0$ & $\$ 0$ \\
\hline \multicolumn{3}{|l|}{ Hospitality justification: N/A } \\
\hline $\begin{array}{l}\text { PROJECT SUPPLIES (office } \\
\text { supplies, postage, printing, etc.) }\end{array}$ & $\$ 0$ & $\$ 50$ \\
\hline \multicolumn{3}{|c|}{$\begin{array}{l}\text { Project supplies justification: Phone and computer service are already in place at the clinic, so there will be no } \\
\text { additional cost for these services. Estimated } \$ 50 \text { for miscellaneous paper, office supplies. Glucometers are provided free } \\
\text { through samples at the clinic as needed; strips are at the expense of the patient or their insurance provider. }\end{array}$} \\
\hline TRAVEL EXPENSES & $\$ 0$ & $\$ 0$ \\
\hline \multicolumn{3}{|l|}{ Travel expenses justification: N/A } \\
\hline TOTALS & $\$ 0$ & $\$ 2,260$ \\
\hline
\end{tabular}




\title{
Appendix
}

I

\author{
Preston Urgent Care Family Practice, LLC. \\ Peggy Phillips, MSN, FNP-BC \\ 411 Morgantown St. \\ Kingwood WV, 26537 \\ Phone: $304-329-0555$
}

Fax: 304-329-0556

September 2, 2013

To Whom It May Concern:

I am quite excited about the opportunity for Kendra Barker, FNP-BC to implement her proposed Capstone Project in the Preston Urgent Care Family Practice, LLC. Through her analysis of our patient clientele, we have discovered that approximately $44 \%$ of our patients with diabetes are currently uncontrolled with an A1C level above 7\%. I am extremely concerned about this high percentage and what it means for the morbidity and mortality of our patients with diabetes. I am writing in support of Kendra's endeavors to target this population with a diabetes education and management project that will enhance our current level of care provided at the clinic. Many of our patients are unable to travel to Morgantown due to transportation issues or cost, so they may not get formal diabetes education other than what handouts and education are provided in their regular office visits. This project will foster some of these patients having an opportunity to gain further teaching and management skills for their diabetes. Our clinic is in full support of this project, and we plan to work in conjunction with Kendra as she implements it according to the SMART Workplan that she has shared with us. We look forward to providing this additional intervention for our patients that may help improve their glycemic control.

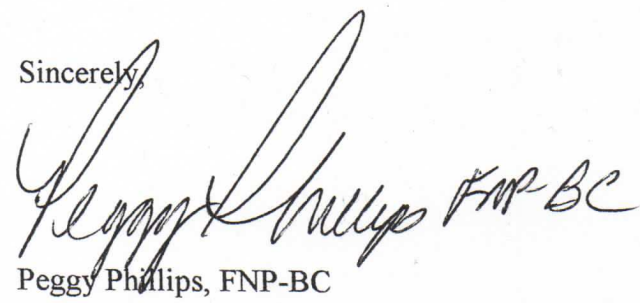




\section{Appendix J}

\section{Paired Samples Test Table for Matched Pre \& Post-BSD Questions}

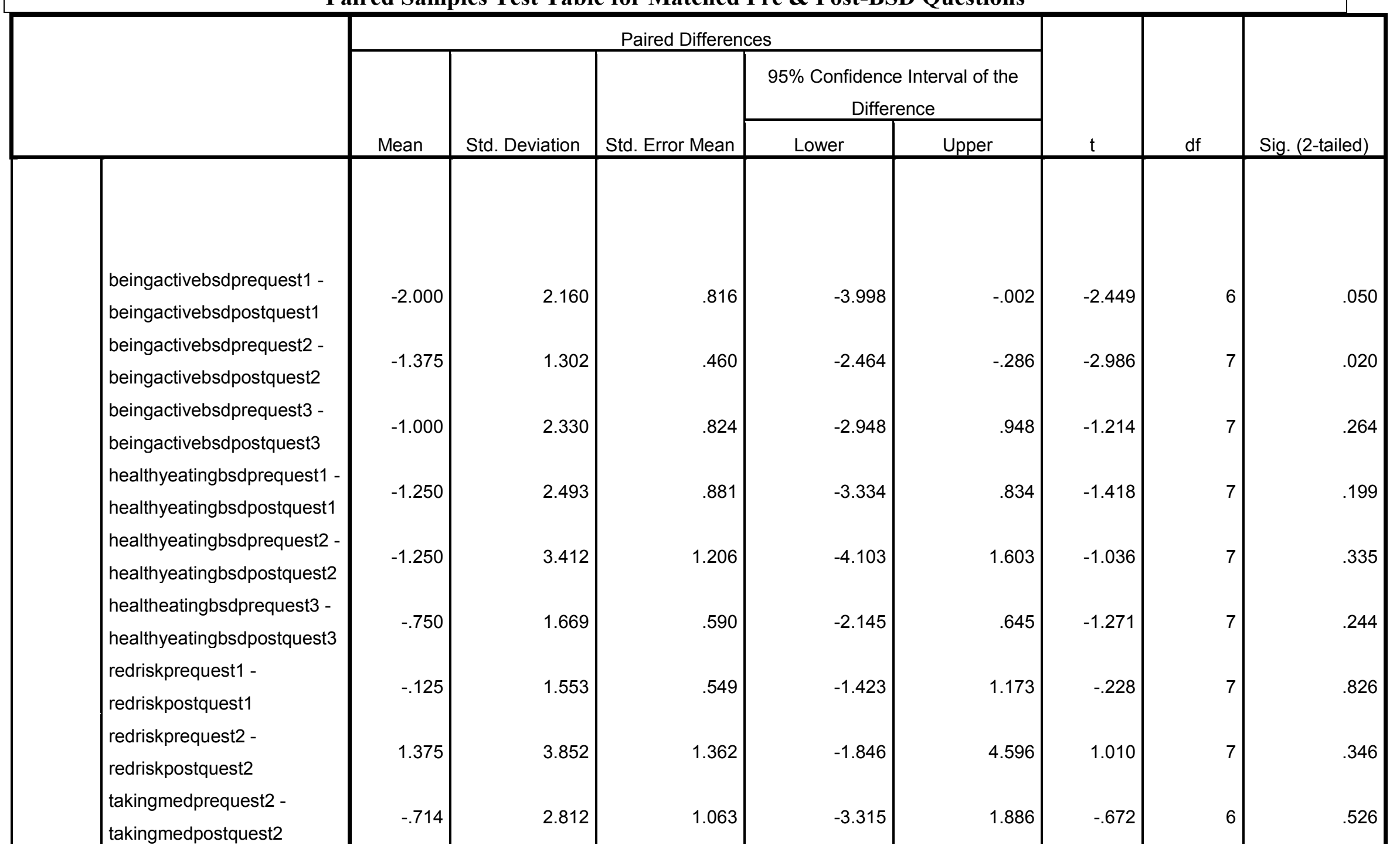




\begin{tabular}{|l} 
takingmedprequest3 - \\
takingmedpostquest3 \\
takingmedprequest4 - \\
takingmedpostquest4 \\
monitoringprequest1 - \\
monitoringpostquest1 \\
monitoringprequest2 - \\
monitoringpostquest2 \\
monitoringprequest3 - \\
monitoringpostquest3 \\
probsolvingprequest1 - \\
probsolvingpostquest1 \\
probsolvingprequest2 - \\
probsolvingpostquest2 \\
probsolvingprequest3 - \\
probsolvingpostquest3 \\
healthycopprequest1 - \\
healthycoppostquest1 \\
healthycopprequest2 - \\
healthycoppostquest2 \\
healthycopprequest3 - \\
healthycoppostquest3
\end{tabular}

\begin{tabular}{|c|c|}
\hline .250 & .463 \\
\hline .625 & .518 \\
\hline .167 & 1.329 \\
\hline .000 & 1.195 \\
\hline-.250 & 2.188 \\
\hline-.125 & 1.126 \\
\hline-.125 & .991 \\
\hline-.500 & 1.069 \\
\hline-.750 & 3.012 \\
\hline .625 & 1.923 \\
\hline .000 & 2.619 \\
\hline
\end{tabular}

\begin{tabular}{|c|c|}
\hline .164 & -.137 \\
\hline .183 & .192 \\
\hline .543 & -1.228 \\
\hline .423 & -.999 \\
\hline .773 & -2.079 \\
\hline .398 & -1.066 \\
\hline .350 & -.954 \\
\hline .378 & -1.394 \\
\hline 1.065 & -3.268 \\
\hline .680 & -.982 \\
\hline .926 & -2.189 \\
\hline
\end{tabular}

\begin{tabular}{|c|c|}
\hline .637 & 1.528 \\
\hline 1.058 & 3.416 \\
\hline 1.562 & .307 \\
\hline .999 & .000 \\
\hline 1.579 & -.323 \\
\hline .816 & -.314 \\
\hline .704 & -.357 \\
\hline .394 & -1.323 \\
\hline 1.768 & -.704 \\
\hline 2.232 & .919 \\
\hline 2.189 & .000 \\
\hline
\end{tabular}




\section{References}

American Association of Clinical Endocrinologists. (2013, November). Retrieved from http://www.aace.com.

American Association of Diabetes Educators. Behavior Score Dashboard. (2013, October). Retrieved from http://www.diabeteseducator.org/ProfessionalResources/AADE7/diabeteseducatortoolbo x.html.

American Diabetes Association. Diabetes Basics \& Living with Diabetes. (2012, April 24) Retrieved from ADA: http://www.diabetes.org/

County Health Rankings and Roadmaps, Preston County, WV. (2012, August 29). Retrieved from http://www.countyhealthrankings.org/about-project.

County Prevalence Data. (2012, March 1). Retrieved from CDC: http://apps.nccd.cdc.gov/DDT_STRS2/CountyPrevalenceData.aspx?mode=DBT

Diabetes Public Health Resource. 2011 National Diabetes Fact Sheet. (2012, March 1). Retrieved from CDC: http://www.cdc.gov/diabetes/pubs/factsheet11.htm

Gallup Wellbeing Poll. (2012, August 27). Retrieved from http://www.gallup.com/poll/156449/Utah-Poised-Best-State-Live.aspx

Healthy People 2020. (2012, October 6). Objective D-5. Retrieved from http://www.healthypeople.gov/2020/topicsobjectives2020/objectiveslist.aspx?topicID=8

International Diabetes Federation Fact Sheet. (2013). Retrieved from International Diabetes Federation: http://www.idf.org/fact-sheets

Mission Statement. Preston Urgent Care Family Practice, LLC. 2012.

SMART plan development. (2013, July 13). Retrieved from: http://library.leeds.ac.uk/skills-smart-planning.

SPSS data analysis from IBM SPSS. (October 10, 2014). Retrieved from: http://www-01.ibm.com/software/analytics/spss/products/statistics/

University of Wisconsin Cooperative Extension. (2012, November 5). Retrieved from Program Development and Evaluation: http://www.uwex.edu/ces/pdande/evaluation/evallogicmodel.html

US Census Bureau 2010 Fact Finder. (2012, September 7). Retrieved from http://factfinder2.census.gov/faces/tableservices/jsf/pages/productview.xhtml?pid=ACS 10 SF4 B01001\&prodType $=$ table 
US Census Bureau 2012 Fact Finder. (2014, October 17). Retrieved from: http://factfinder2.census.gov/faces/tableservices/jsf/pages/productview.xhtml?src=CF.

WV Diabetes Prevention and Control Program Surveillance and Statistics Fact Sheet. (2012, March 1). Retrieved from WV DHHR:

http://www.wvdiabetes.org/Portals/12/DiabetesFactSheet_withfinal7thfloorchanges.pdf

Behringer, B., \& Friedell, G. H. (n.d.). Appalachia: Where place matters in health. Preventing Chronic Disease. Public Health Research, Practice, and Policy, 3(4), 1-4.

Bloomgarden, Z. (2007). Does a structured patient education program improve glycemic control in individuals with type 2 diabetes mellitus? Nature Clinical Practice Endocrinology \& Metabolism, 3(5), 390-391.

Boyle, J. P., Thompson, T. J., Gregg, E. W., Barker, L. E., \& Williamson, D. F. (2010). Projection of the year 2050 burden of diabetes in the US adult population: dynamic modeling of incidence, mortality, and prediabetes prevalence. Population Health Metrics, $8(29)$.

Burke, R. E., \& O'Grady, E. T. (2012). Group visits hold great potential for improving diabetes care and outcomes, but best practices must be developed. Health Affairs, 31(1), 103-109.

Chart Audit, PUCFP. July 2012. Audit for all patients with an electronically coded diagnosis of diabetes.

Chen, H. S., Wu, T. E., Jap, T. S., Lin, S. H., Hsiao, L. C., \& Lin, H. D. (2008). Improvement of glycaemia control in subjects with type 2 diabetes by self-monitoring of blood glucose: comparison of two management programs adjusting bedtime insulin dosage. Diabetes, Obesity \& Metabolism, 10, 34-40.

Cinar, F., Akbayrak, N., Cinar, M., Karadurmus, N., Sahin, M., Dogru, T., \& Kilic, S. (2010). The effectiveness of nurse-led telephone follow-up in patients with type 2 diabetes. Turkish Journal of Endocrinology \& Metabolism, 14(1), 1-5.

Coberley, C., Hamar, B., Gandy, B., Orr, P., Coberley, S., McGinnis, M., . . Pope, J. (2007). Impact of telephonic interventions on glycosolated hemoglobin and low-density lipoprotein cholesterol testing. The American Journal of Managed Care, 13(4), 188-192.

Deshpande, A., Harris-Hayes, M., \& Schootman, M. (2008). Epidemiology of diabetes and diabetes-related complications. Physical Therapy, 88(11), 1254-1264.

Donnelly, J. (2003). Losing hope in Appalachia. The Boston Globe. 
Frosch, D., Uy, V., Ochoa, S., \& Mangione, C. (2011). Evaluation of a behavior support intervention for patients with poorly controlled diabetes. Archives of Internal Medicine, 171(22), 2011-2017.

Greene, J. A., Choudhry, N. K., Kilabuk, E., \& Shrank, W. H. (2011). Online social networking by patients with diabetes: A qualitative evaluation of communication with facebook. Journal of General Internal Medicine, 26(3), 287-292.

Huttlinger, K. W., \& Purnell, L. D. (2008). People of Appalachian heritage. In Transcultural Health Care: A culturally competent approach (pp. 95-112). Philadelphia: F.A. Davis.

Kim, H.-S., \& Oh, J.-A. (2003). Adherence to diabetes control recommendations: impact of nurse telephone calls. Journal of Advanced Nursing, 44(3), 256-261.

Larrabee, J. (2009). Nurse to Nurse: Evidence-Based Practice. New York: McGraw-Hill.

Maljanian, R., Grey, N., Staff, I., \& Conroy, L. (2005). Intensive telephone follow-up to a hospital-based disease management model for patients with diabetes mellitus. Disease Management, 8(1), 15-25.

Mallow, J., Theeke, L., Barnes, E., Whetsel, T., (July, 2013). "Diabetes Group Medical Visits and Outcomes of Care in Low-Income, Rural, Uninsured Persons." Open Journal of Nursing.

Martin, A. (2012). Changes and consistencies in diabetes education over 5 years. The Diabetes Educator, 38(1), 35-46.

Pare, G., Moqadem, K., Pineau, G., \& St-Hilaire, C. (2010). Clinical effectts of home telemonitoring in the context of diabetes, asthma, heart failure and hypertension: A systematic review. Journal of Medical Internet Research, 12(2), e21.

Polisena, J., Tran, K., Cimon, K., Hutton, B., McGill, S., \& Palmer, K. (2009). Home telehealth for diabetes management: a systematic review and meta-analysis. Diabetes, Obesity, and Metabolism, 11, 913-930.

Sacco, W., Malone, J., Morrison, A., Friedman, A., \& Wells, K. (2009). Effect of a brief, regular telephone intervention by paraprofessionals for type 2 diabetes. Journal of Behavioral Medicine, 32(4), 349-359.

Scottish Intercollegiate Guidelines Network, SIGN (2007). Critical Appraisal: Notes and Checklist. Retrieved from: http://www.sign.ac.uk/methodology/checklists.html.

Skinner, E. (2010). Integrative health coaching for patients with type 2 diabetes: A randomized clinical trial. The Diabetes Educator, 36, 629-639. 
Smith, S. L., \& Tessaro, I. A. (2005). Cultural perspectives on diabetes in an appalachian population. American Journal of Health Behavior, 29(4), 291-301.

Takahashi, P. Y., Pecina, J. L., Upatising, B., Chaudhry, R., Shah, N. D., Houten, H. V., . . Hanson, G. J. (2012). A randomized controlled trial of telemonitoring in older adults with multiple health issues to prevent hospitalizations and emergency department visits. Archives of Internal Medicine, 172(10), 773-779.

Tompkins, C., \& Orwat, J. (2010). A randomized trial of telemonitoring heart failure patients. Journal of Healthcare Management, 55(5), 312-322.

Valdez, R., Yoon, P. W., Liu, T., \& Khoury, M. J. (2007). Family history and prevalence of diabetes in the U.S. population: the 6-year results from the National Health and Nutrition Examination Survey. Diabetes Care, 30(10), 2517-22.

Walker, E. A., Siimukler, C., Ullman, R., Blanco, E., Scollan-Koliopoulus, M., \& Cohen, H. W. (2011). Results of a successful telephonic intervention to improve diabetes control in urban adults. Diabetes Care, 34(1), 2-7.

Wolever, R. Q., Dreusicke, J. F., Hawkins, T. V., Yeung, S., Wakefield, J., Duda, L., . . . Skinner, E. (2010). Integrative health coaching for patients with type 2 diabetes: A randomized clinical trial. The Diabetes Educator, 36, 629-639. 